\title{
Diversity of supergene gold expressions and implications for gold targeting in an equatorial regolith (AMG's Couriège exploration prospect, French Guiana)
}

Vincent Combes ${ }^{1,2}$, , Yoram Teitler ${ }^{1}$, Aurélien Eglinger ${ }^{1}$, Anne-Sylvie Andre-Mayer ${ }^{1}$, Arnauld Heuret $^{3}$, Anthony Pochon ${ }^{4}$, Michel Cathelineau ${ }^{1}$, Pierre Gibert ${ }^{2}$

${ }^{1}$ Université de Lorraine, CNRS, CREGU, GeoRessources, 54500 Nancy, France

${ }^{2}$ AMG, Auplata Mining Group, ZI Dégrad des Cannes, 97354, Rémire Montjoly, France

${ }^{3}$ Université de Guyane / Géosciences Montpellier (UMR 5243), 97300 Cayenne, France

${ }^{4}$ Institut des Sciences de la Terre d'Orléans (ISTO) UMR 7327, Université d'Orléans - CNRS

- BRGM, Campus Géosciences, 1A rue de la Férollerie, 45071 Orléans, Cedex 2, France

* corresponding author (vincent.combes@univ-lorraine.fr)

\begin{abstract}
The Couriège prospect (French Guiana) provides key examples of the diversity of gold distribution related to supergene processes. The nature of gold in two contrasted weathering profiles is examined as a function of the weathering lithofacies. The autochthonous profile hosts weathered Au-bearing quartz veins whereas the pediment profile is enriched in free gold issued from dismantled gold-bearing quartz veins. The gold distribution is controlled by: (i) the preservation of primary gold as free gold in both transported and autochthonous horizons and as electrum inclusions in detrital pyrite, and (ii) the formation of secondary gold through dissolution/precipitation processes, expressed as gold spherulites on free gold grain surface, Ag-depleted rim around transported free gold grains and Ag-depleted gold micro-inclusions hosted by oxidised autochthonous pyrite. Gold enrichment through supergene chemical processes remains limited within the truncated autochthonous profile. A new conceptual model is proposed for the area, defining the role of chemical and physical processes in gold endowment, and accounting for the geomorphological context. The overall evolution includes (i) deep weathering and peneplenation, (ii) dismantlement and transport of lateritic material, and (iii) development of a latosol cover. This study highlights that gold exploration in tropical environments must consider the residual vs transported nature and the inheritance of targeted pedogenic horizons.
\end{abstract}

Keywords: weathering, gold, transported cover, saprolite, French Guiana, supergene 


\section{Introduction}

The Guiana Shield (Fig. 1A) in South America is an important mineral province hosting significant gold resources which are attractive for the exploration of gold deposits (Voicu et al., 2001; Milesi et al., 2003; Daoust et al., 2011; Velasquez et al., 2014; Tedeschi et al., 2018a; Guiraud et al., 2020, Combes et al., 2021). However, due to its low latitude geographic position, the Guiana Shield is covered mainly by a well-developed regolith and equatorial rainforest, representing a challenging environment for exploration (Freyssinet et al., 1989, 2005; Butt, 1998; Butt et al., 2000; Anand \& Butt, 2010; Theveniaut \& Freyssinet, 2002; Butt, 2015; Sunkari et al., 2019). In addition, supergene processes can either hinder or modify primary (i.e., hypogene) gold resources (Anand \& Paine, 2002; Anand et al., 2019) through weathering, erosion and pedimentation. In particular, the impact of deep weathering and laterite formation on primary gold commonly leads to secondary gold resources (Craw et al., 2015; Craw \& Kerr, 2017 and references therein). Such resources are economically profitable as they represent easily accessible targets because they consist of poorly consolidated material that is readily mineable.

It is essential to acknowledge the variability, depending on authors, of the terminology employed to describe the deep weathering horizons, which is a source of confusion. For this study, the terminology of Anand et al. (2002) was followed. The term duricrust is used for regolith materials cemented by $\mathrm{Fe}$, irrespective of the substrate origin. Where residual, the Fecemented material is referred to as lateritic residuum. Where formed and indurated in a transported cover (i.e. pediment), it is referred to as ferricrete. Autochthonous horizons underwent no physical transport (Colin et al., 1989) when pediments involve dismantlement, transport, and material deposition. Therefore, the associated gold expressions in the different horizons need to be related to the geomorphological context.

Deep weathering processes are associated with active gold remobilisation through dissolutionreprecipitation, grain coarsening and increase in fineness with the formation of Ag-poor rims (Colin \& Lecomte, 1989; Freyssinet et al., 1989; Colin \& Vieillard, 1991; Bamba et al., 2002; Larizzatti et al., 2008; Falconer \& Craw, 2009). Several models suggest that the gold redistribution in deep weathering profiles may exhibit one or two mushroom-shaped dispersion zones from the mineralised vein. In humid and tropical rainforest regions, gold mineralisation halo is observed within the lateritic residuum and the upper portion of the mottled zone. In semi-arid environments, post-lateritic remobilisation occurs through the dissolution of gold by acid and saline groundwaters and gold reprecipitation deeper in the profile within the saprolite 
(Costa et al., 1993; Freyssinet et al. 1989a, 1989b, 2005; Butt \& Smith, 1980; Colin \& Vieillard, 1991; Freyssinet, 1993; Freyssinet \& Itard, 1997).

Experimental studies confirm that, under the conditions that prevail during lateritic weathering, gold is dissolved and transported as gold chloride and thiosulfate complexes (Benedetti \& Boulègue, 1991; Pokrovski et al., 2014; Perera et al., 2005; Zotov et al., 2018). The rate of gold dispersion remains somewhat limited but insufficiently known (Bowell et al., 1993; Vishiti et al., 2015; Horbe et al., 2019). Therefore, understanding the influence of supergene processes on gold mobility is critical for exploring gold resources in regolith-dominated terranes, particularly in French Guiana.

In French Guiana, gold occurs in orogenic gold deposit hosted by greenstone belts (Milesi et al., 2003; Combes et al., 2021). This region is submitted since Cretaceous times to equatorial climate and underwent significant lateritic weathering. The relative impact of weathering on primary gold ore remains poorly studied at the scale of the deep weathering profile, encouraging a detailed study of profiles developed on areas where primary gold ores are known within the bedrock. The Couriège prospect in French Guiana provides suitable conditions for such investigations. Two Au-bearing weathering profiles were selected for the diversity of their supergene gold expressions (residual vs transported; Fig. 1B and C).

The profiles were therefore studied to (1) document the mineralogical and geochemical changes associated with the deep weathering processes, (2) assess the scale of the vertical and lateral gold dispersion from auriferous veins, (3) evaluate the compositional and morphological evolution of gold grains during weathering, (4) discuss the supergene processes involved during deep weathering depending on the type of gold-bearing horizon (autochthonous vs transported), and (5) identify the implication for gold targeting, considering possible issues such as false positive/negative anomalies at surface. From a self-contained holistic study at Couriège, a more widely beneficial discussion is proposed regarding surface to near-surface exploration surveys in tropical environments. Particular attention was devoted to the in situ distribution of gold in the poorly consolidated latosols, mottled zone and saprolite horizons, representing important targets for supergene gold exploration within the Guiana Shield (Dardenne \& Schobbenhaus, 2003).

\section{Regional geology}

The geologic environment of the Couriège prospect, owned by AMG (Auplata Mining Group), is intimately related to the Trans-Amazonian orogeny. The Trans-Amazonian cycle begins with an Eorhyacian oceanic stage (ca. 2.26-2.20 Ga) between the West African and North 
Amazonian Archaean cratons (Vanderhaeghe et al., 1998; Delor et al., 2003a, b). The closure of this domain by subduction during the Mesorhyacian (ca. 2.18-2.13 Ga) induces the emplacement of TTG-type intrusions related to magmatic arcs. Volcano-sedimentary formations are also developed during the subduction-related D1 deformation phase (Ledru et al., 1991; Milési et al., 1995; Vanderhaeghe et al., 1998; Delor et al., 2003a, b). The end of the subduction process is marked by the tectonic accretion of the different sets of magmatic arcs and the closure of the volcano-sedimentary basins during the Neorhyacian period (ca. 2.11-2.08 Ga) with regional scale sinistral strike-slip faults referred to as the D2a stage (Delor et al., 2003a, b). These transcurrent tectonic events allow the development of late extensional basins (Ledru et al., 1991) filled by detrital sediments (the Upper Detrital Unit; Fig. 1B) during a D2b deformation phase (2.07-2.05 Ga) marked by crustal stretching and metaluminous to peraluminous granite emplacement (Vanderhaeghe et al., 1998; Delor et al., 2003a, b).

To sum up, the geological formations outcropping and then weathered in French Guiana can be divided into five lithotectonic units (Vanderhaeghe et al., 1998; Delor et al., 2003a, b and references therein), namely (1) the "Ile de Cayenne" complex witnessing a potential juvenile oceanic crust, (2) the Paramaca Greenstone Belts characterised by volcano-sedimentary sequences, (3) the TTG complexes represented by tonalite-trondhjemite-granodiorite suites, (4) the Upper Detrital Unit dominated by conglomerates, pelites and sandstones and (5) the metaluminous to peraluminous granites.

Within this tectonic-lithological framework, four types of gold-bearing deposits are currently identified: (1) Au-rich VMS (Volcanogenic Massive Sulphide) deposit as characterised by Franklin et al. (2000) and Guiraud et al. (2017, 2020) at Montagne d'Or; (2) stratiform/stratabound gold-bearing tourmalinites with disseminated sulphides as observed at Dorlin (Milesi et al., 2003) with an overprinting of late orogenic gold mineralisation dated at ca. 2.06 Ga (Marcoux \& Milési, 1993); (3) gold-bearing polygenic conglomerates hosted by the Upper Detrital Unit, exampled at Montagne Tortue (Milesi et al., 1995) where the mineralisation is multi-stage with an orogenic gold overprinting expressed by quartztourmaline veining (Milesi et al., 2003) and (4) orogenic gold deposits as observed at Yaou, Esperance, Loulouie, Boulanger and Camp Caïman (Milesi et al., 2003). In the latter type of deposit, the mineralisation is mainly visible gold (e.g. micro-inclusions in sulphides and free gold), as in the Yaou deposit (Combes et al., 2021). However, this primary (hypogene) gold resource represents only a fraction of the overall gold resource in French Guiana. Indeed, according to Picot \& Chevillard (2015), alluvial placers resources could represent about 167 
tons of gold, while laterite-bearing and primary gold would account for 210 tons of gold altogether. Also, it is worth noticing that, as previously mentioned by Voicu et al. (2001), average gold grades are ranging between 1.3 and $2.3 \mathrm{~g} / \mathrm{t}$ Au for most gold deposits of the Guiana Shield.

The formation of deep weathering and placer gold deposits in French Guiana and more generally across the Guiana Shield is assumed to be related to the recent (i.e. Phanerozoic) geomorphological and weathering history that shaped the modern landscape of the region (Theveniaut \& Freyssinet, 2002). Lateritisation and erosion-transport processes affected primary gold occurrences and deposits, resulting in the development of deeply weathered goldbearing regolith and placers, respectively. Across French Guiana, Theveniaut \& Freyssinet (2002) recognised a succession of lateritisation and erosion phases associated with the formation of secondary gold deposits, including (1) early (Paleocene-Eocene) lateritic weathering corresponding to the Sul Americano lateritisation cycle at ca. 50-40 Ma resulting from the warm and perhumid conditions that prevailed during the Paleocene-Eocene Thermal Maximum (PETM); (2) a substantial erosion period during the Oligocene, at ca. 30-23 Ma; and (3) a late Miocene lateritisation event, known as the Late Velhas cycle at ca. 13-5 Ma. Regarding the time scale of lateritisation, Freyssinet \& Farah (2000) estimated, along with a lateritic profile at Yaou, a saprolitisation and a latosol development rate of 7.5 and $4.5 \mathrm{~m} / \mathrm{Ma}$, respectively, thus resulting in a chemical thickening rate of $3 \mathrm{~m} / \mathrm{Ma}$. Girard et al. (1997, 2000) propose, from oxygen and hydrogen isotopic composition of goethite and kaolinite in laterites from Yaou, a change in climatic regime from tropical wet and dry (seasonal) in the past (possibly as old as Upper Jurassic or Cretaceous) to equatorial in the present day.

So far, no real constraints exist on the age of lateritic gold deposits in French Guiana. However, they are presumably related to the Sul Americano and the Late Velhas lateritisation periods and formed from residual accumulations of gold during the Eocene to the Late Tertiary (MiocenePliocene) (Dardenne \& Schobbenhaus, 2003). In addition, Costa et al. (1993) highlighted that supergene enrichment has been essential for increasing the gold concentration at the Cassiporé deposit in NE Brazil. However, it is not demonstrated that the contribution of supergene processes is significant in upgrading the primary gold budget in the Guiana region.

\section{Prospect-scale geology and topography}


The Couriège prospect is located within the St Elie district in the Northern Palaeoproterozoic Paramaca Greenstone Belt in French Guiana (Fig. 1B), more precisely at the contact between the Lower Volcano-sedimentary unit (Paramaca) at the East and the Central TTG complex at the West (Fig. 1C). At the East, the Dieu-Merci concessions (Fig. 1C) are characterised by subvertical pyrite-rich shear veins spatially associated with subhorizontal extensional veins (Auplata Mining Group internal reports). They display similar features to those described in the nearby Devis and Michel zones (St Elie district) (Lafrance et al., 1999), where Au-bearing quartz veins are associated with ductile shear zones. The Couriège area is an exploration-only tenement, explored since the 1990s by Guyanor and later by Auplata Mining Group with indications of a three km-long mineralised zone with discontinuous, 2 to $15 \mathrm{~m}$ large orebodies. This zone coincides with the presence of dismantled, subhorizontal, Au-bearing quartz \pm pyrite veins at the subsurface, which can be related to orogenic gold processes. The elevation of the Couriège prospect is moderate and ranges from $56 \mathrm{~m}$ to $225 \mathrm{~m}$ above sea level (AMG Digital Elevation Model). Morphology includes dissected lateritic residuum plateaus, flattened hills, landslides, together with alluvial plains that host placer gold resources (Fig. 2A and B).

Although no comprehensive regolith mapping is available in the prospect area, a preliminary analysis of the topographic context at the prospect-scale is proposed, based on the identification of planation surfaces from the Digital Elevation Model (Fig. 2A). In the prospect area, topographic transects indicate that the highest relief corresponds to a single hill (referred to as the Lupe hill) with a maximum elevation of about $225 \mathrm{~m}$ above sea level. The top of the Lupe hill is the relict of an old, now dismantled, duricrust surface (S1), as supported by local exposures of lateritic residuum (Fig. 2B). Topographic transects revealed two other planation surfaces at intermediate elevations. The S2 surface corresponds to the top of flat hills at altitudes of about 130-140 m; it is not clear whether this surface represents remnants of duricrust plateaus formed in situ from chemical weathering only or whether it corresponds to an ancient glacis surface. The S3 surface corresponds to the alluvial plain of an almost closed, kilometric watershed located in the northeastern part of the prospect, at an elevation of about $100 \mathrm{~m}$ (Fig. 2A), only connected to (yet not levelled with) the main watershed through a narrow, stepped exutory. The S4 surface corresponds to the main watershed alluvial plain representing the active pediplanation surface at elevations of about 70-80 m. According to Chardon et al. (2018), field investigations and topographic interpretations conducted at the scale of a few square kilometres are generally not sufficient to properly constrain the landscape chronology due to the lateral variability of the paleo-landform preservation, so that the proposed topographic analysis must be considered cautiously. 
A $50 \mathrm{~cm}$ deep soil gold geochemical survey was conducted in the studied area in 1997 (data from AMG; over 5000 analyses of soil samples) with returning assay values ranging from below detection limit to $3000 \mathrm{ppb} \mathrm{Au}$ (Fig. 2B). Based on available exploration data, the gold occurrences are usually located on the slopes of flattened hills, near the base of slopes that flank the S3 planation surface (Fig. 2B). There is a limitation in using and interpreting the soil geochemistry anomalies in this area as transported covers and alluvial horizons are present in various places. With no drillcore data and only moderate exploration trenches data available, the prospect is nearly devoid of bedrock outcrops. Only a few exposures have been identified distal to the mineralised zones delimited by the AMG subsurface trenching campaign.

\section{Sampled material and analytical methods}

The Achman Giraud site, located in the central part of the Couriège tenement near the top of a small hill (Fig. 2) at an intermediate elevation between the S2 surface and the active S4 alluvial plain, was selected for the accessibility to a semi-complete weathering profile that hosts partly dismantled, high grade (1.4 to $39.5 \mathrm{~g} / \mathrm{t} \mathrm{Au}$ ) quartz veins (exploration data AMG), together with the accessibility to nearby bedrock exposures. The Lupe site, located in the NW part of the Couriège prospect (about $1 \mathrm{~km}$ SE from Lupe) within the southern, lower slope portion of the Lupe hill (Fig.2), was selected for the documented presence of an auriferous transported cover. Two trenches at the Achman Giraud and Lupe sites were prepared for mapping and sampling along the trench wall surfaces (trench dimensions: $12 \mathrm{~m}$ long $-8 \mathrm{~m}$ deep at Achman Giraud, 20 $\mathrm{m}$ long $-4.5 \mathrm{~m}$ deep at Lupe). At Achman Giraud, channel sampling was conducted along two vertical profiles to account for the vertical gradation of the weathering sequence, including one profile that intersects a $50 \mathrm{~cm}$-thick auriferous quartz vein. Sampling was also conducted along two lateral profiles, i.e., from the mineralised vein outwards, at different positions within the weathering sequence. In addition, one unaltered bedrock sample was collected along a nearby stream (Fig. 2B). At Lupe, channel sampling was conducted along two vertical profiles and complemented with hand sampling of cm-large detrital pyrite crystals. Samples collected from channel sampling were processed for (1) whole-rock gold grade analysis; (2) whole-rock trace and major element analysis; (3) whole-rock mineralogical analysis (XRD); (4) free gold flakes collection (panning), and (5) thick $(200 \mu \mathrm{m})$ section manufacturing for optic and scanning electronic microscopy, electron probe and XRF microanalysis. Detrital pyrite crystals collected at the Lupe site were prepared as polished sections. 
Whole-rock gold grade analyses

Twenty-six samples (mainly from the Achman Giraud site) were analysed for whole-rock gold grades at the Filab laboratory in Paramaribo, Suriname. Analyses were conducted using Fire Assay (ICP-AES) on $50 \mathrm{~g}$ pulps obtained from drying, crushing, splitting, and pulverising of $\sim 1000$ g samples.

Whole-rock analyses of trace and major elements

Twenty-three hand specimens (mainly from the Achman Giraud site) were split and crushed using an agate bowl pulveriser at GeoRessources Laboratory (Nancy, France). Pulps were analysed for whole-rock major- and trace-element geochemistry at the SARM analytical service of the CRPG (Carignan et al., 2001). Major element oxides were analysed using an iCap6500 ICP-OES with Li borate fusion. Trace elements were analysed using an iCapQ ICP-MS with Li borate fusion followed by nitric acid digestion. Loss on ignition (LOI) was determined by drying sample powders, ignition at $1100{ }^{\circ} \mathrm{C}$ and subsequent measurement of the weight loss. Analytical accuracy ( $2 \sigma$ standard deviation) lies within the typical uncertainty of the analytical data for both major oxides and trace elements, that is $<1 \%$ for major oxides and $<5 \%$ for most trace elements. The laboratory procedure for whole-rock analyses excludes Te and Ag.

XRD analyses on powder

Mineral assemblages were identified using X-ray diffraction (XRD) analysis performed on rock powders. X-ray diffraction patterns were collected at the GeoRessources laboratory using a D2 phaser X-ray diffractometer, operating in step scan mode, with $\mathrm{CuK} \alpha$ radiation $(30 \mathrm{kV}, 10 \mathrm{~mA})$. Patterns were collected in the range $2-90^{\circ} 2 \theta$ with a step size of $0.016^{\circ}$ and a rate of $0.4 \mathrm{~s}$ per step.

Imagery and geochemistry of free gold grains

Regolith materials collected along the two investigated sites were panned on the field. Collected heavy minerals were dried, and gold grains were handpicked under a binocular microscope at the GeoRessources laboratory. It is worth noticing that the manual panning method permits to recover large gold grains $(>300 \mu \mathrm{m})$ but results in the loss of smaller-sized gold grains, thus leading to significant sampling biases. For optical examination of morphology and surface, forty two grains were placed on the double taped band. They were examined using a 3D macroscope (VHX 2000 Keyence) followed by high-resolution Scanning Electron Microscopy 
(SEM) observations on a Hitachi FEG S4800 using SE imaging mode with beam conditions of $10 \mathrm{kV}$ and $10 \mathrm{nA}$ at the SCMEM at the GeoRessources laboratory (Nancy, France).

Selected representative grains from each horizon were then polished and mounted in a resin mount. Grains were classified according to their morphology and studied by SEM (TESCAN VEGA3) and electron probe micro-analyser, (EPMA, CAMECA SX-100) at the GeoRessources laboratory with an acceleration voltage of $20 \mathrm{kV}$ and beam current of $20 \mathrm{nA}$ : 116 spot analyses were performed for $\mathrm{Au}, \mathrm{Ag}, \mathrm{As}, \mathrm{Bi}, \mathrm{Te}, \mathrm{Sb}, \mathrm{Cu}, \mathrm{Ni}, \mathrm{Co}$ and $\mathrm{Fe}$. Standard specimens used for calibration were $\mathrm{FeS}_{2}$ (for $\mathrm{Fe}$ ) and pure metals for $\mathrm{Au}, \mathrm{Ag}, \mathrm{As}, \mathrm{Te}, \mathrm{Cu}, \mathrm{Ni}$ and $\mathrm{Co}$. Only Ag, Au and rarely $\mathrm{Cu}$ present contents above detection limits. Chemical zonations have been tested on seven representative grains by performing X-rays maps (EPMA) of Au, $\mathrm{As}, \mathrm{Cu}, \mathrm{Te}$ and $\mathrm{Ag}$.

Trace element composition of gold grains was further investigated from LA-ICP-MS analyses at the BRGM laboratory in Orléans (France). The following elements were analysed: ${ }^{52} \mathrm{Cr},{ }^{33} \mathrm{~S}$, ${ }^{55} \mathrm{Mn},{ }^{58} \mathrm{Ni},{ }^{59} \mathrm{Co},{ }^{63} \mathrm{Cu},{ }^{64} \mathrm{Zn},{ }^{75} \mathrm{As},{ }^{76} \mathrm{Se},{ }^{78} \mathrm{Se},{ }^{82} \mathrm{Se},{ }^{103} \mathrm{Rh},{ }^{105} \mathrm{Pd},{ }^{106} \mathrm{Pd},{ }^{107} \mathrm{Ag},{ }^{109} \mathrm{Ag}, \mathrm{Cd},{ }^{114} \mathrm{Cd}$, ${ }^{118} \mathrm{Sn},{ }^{120} \mathrm{Sn},{ }^{121} \mathrm{Sb},{ }^{123} \mathrm{Sb},{ }^{130} \mathrm{Te},{ }^{195} \mathrm{Pt},{ }^{197} \mathrm{Au},{ }^{202} \mathrm{Hg},{ }^{208} \mathrm{~Pb}$ and ${ }^{209} \mathrm{Bi}$. Sulphur $\left({ }^{33} \mathrm{~S}\right),{ }^{57} \mathrm{Fe}$ and ${ }^{48} \mathrm{Ti}$ were monitored to detect potential contribution from sulphides and Fe-Ti oxides inclusions, respectively. The LA-ICP-MS system consists of an excimer laser (193 nm) CETAC Excite coupled to ThermoScientific X Serie II quadrupole plasma mass spectrometer. The laser is equipped with a HelEx ${ }^{\circledR} 2$ volume ablation cell that optimises the material transport to the ICPMS. The ablated material is carried by $\mathrm{He}$, mixed with $\mathrm{N}_{2}$ and Ar, before injection into the plasma source. Instrument and mass calibration alignment were performed before each analytical session on the NIST SRM 612 reference material. To enhance the signal and reach very low detection limits for analysed trace elements, a beam diameter of $85 \mu \mathrm{m}$ was used, and ablation areas were carefully selected to avoid solid micro-inclusions. One single analysis consists of $20 \mathrm{~s}$ of gas blank followed by $40 \mathrm{~s}$ of ablation. A laser pulse frequency of $8 \mathrm{~Hz}$ and a laser beam energy of $3.06 \mathrm{~J} / \mathrm{cm}^{2}$ were used during analyses. Quantification of gold was carried out using ${ }^{107} \mathrm{Ag}$ as internal standard. For each analytical session, we used the following standard bracketing procedure: one analysis of the RAuP7 and RAuP3 gold reference materials from MBH every ten analyses of gold grains and one analysis of the NA-Au-31 and NA-Au-30 gold standards (Kovacs et al. 2009) for every twenty analyses of gold grains. This sequence was then repeated up to the end of the session. Calibration of $\mathrm{Ni}, \mathrm{As}, \mathrm{Cd}, \mathrm{Sn}$ and Te was performed using reference material NA-Au-31. For the remaining elements, the RAuP7 gold standard was used for calibration. To monitor the quality of analyses, we used the reference materials NA-Au-30 
and RAuP3. The NA-Au-30 and RAuP3 standards measurements were treated as unknowns and used to control the reproducibility and accuracy of analyses. Data reduction was carried out using Iolite software (Patton et al., 2011). Analyses of RAuP3 show high accuracy and excellent precision, with a mean relative difference (RD) $\sim 4.4 \%$ and relative standard deviations (RSD) $\sim 9.8 \%$ for all considered elements. ${ }^{121} \mathrm{Sb}$ and ${ }^{208} \mathrm{~Pb}$ are slightly overestimated by $12-14 \%$. Note that ${ }^{209} \mathrm{Bi}$ have the largest RSD of $32 \%$. Regarding the NA-Au-30, analyses show good accuracy and excellent precision, with a mean RD of $\sim 8 \%$ and a mean RSD of $\sim 8.8 \%$. ${ }^{114} \mathrm{Cd}$ and ${ }^{118} \mathrm{Sn}$ are underestimated by $25 \%$.

Microscopic observations and analysis on thick sections

A total of thirteen impregnated (epoxy resin) thick sections have been manufactured, including eleven thick sections encompassing all the horizons observed at Achman Giraud and two thick sections of cm-large detrital pyrites collected at Lupe. Thick sections were examined using reflected/transmitted light and scanning electron microscopy (TESCAN VEGA3 and JEOL $\mathrm{J} 7600 \mathrm{~F}$, providing backscattered electron mode images at an acceleration voltage of $20 \mathrm{kV}$ ) to characterise mineral assemblages, parageneses and possible occurrences of in situ gold. EPMA spot analysis was conducted on microscopic (in situ) gold occurrences identified from optical and scanning electron microscopy, with analytical conditions identical to those used for EPMA spot analysis of large $(>300 \mu \mathrm{m})$ free gold grains. Chemical micro-XRF maps were acquired using the M4 TORNADO analyser with beam conditions of $50 \mathrm{kV}$ and $600 \mathrm{~mA}, 25 \mu \mathrm{m}$ spatial resolution and $12 \mathrm{~ms} /$ pixel dwell time. Micro-XRF maps were processed to obtain quantitative mineral maps using the open-source MARCIA Python routine (Meyer and Cauzid, 2020). MARCIA permits mineral classification by defining masks that are a linear combination of elemental intensities in spectra. EPMA mapping was also conducted on one mm-large crystal of goethite pseudomorph after pyrite from the Achman Giraud site (analysed elements are Si, Fe, S, Bi, Ti, Ag, Al, Te and Au).

\section{Results}

\section{Macroscopic observations}

Achman Giraud profile

The weathering profile at the Achman Giraud site, exposed along a SSW-NNE trench, presents an undisturbed succession of weathering horizons (Fig. 3A). The base of the profile consists of 
a mafic-derived, fine-grained purplish saprolite wherein the primary fabric is partly preserved (Fig. 3A, C and D). The saprolite horizon sharply grades upwards into the mottled zone, characterised by a kaolinite-rich matrix locally containing $\mathrm{cm}$-scale, hematite-bearing mottles with typical reddish colouration (Fig. 3A, B and C). The mottled zone, whose thickness does not exceed a few tens of centimetres, is laterally discontinuous and locally pinches out in the central part of the exposed profile. Upwards, there is an evolution into the pulverulent red latosol wherein kaolinite still represents the predominant mineral phase. Diffuse hematisation results in a homogeneous reddish colouration of this horizon (Fig. 3A). Above, the uppermost metre of the profile consists of a light brownish horizon (brown latosol) wherein ochreous goethite (limonite) forms at the expense of hematite (Fig. 3A). Sigmoidal, moderately dipping quartz veins about 10 to $60 \mathrm{~cm}$-thick (Fig. $3 \mathrm{~A}$ and D) are observed in all horizons except within the brown latosol. This observation, together with the gradual evolution from the red latosol to the brown latosol and the apparent absence of any clastic beds, further support the assumption that the entire weathering profile is autochthonous. Quartz veins are weakly to moderately dismantled and locally contain late manganese oxides, and clay infills were fractured. Importantly, the quartz vein contains (i) visible, mm-large gold flakes and (ii) goethite pseudomorphs after mm-to cm-large pyrite crystals exhibiting boxwork alteration textures. Neither the saprock nor the unweathered bedrock was directly exposed within the sampled trench. Nevertheless, one sample of unweathered, foliated amphibolite was collected along a stream situated about $180 \mathrm{~m} \mathrm{NW}$ from the Achman Giraud site (Figs. 2B and 3A). The Achman Giraud weathering profile probably developed on the amphibolite observed more in-depth in the bedrock as a preliminary conclusion.

\section{Lupe}

The weathering profile at the Lupe site is exposed along an E-W trench and consists of a sequence of autochthonous horizons truncated by a transported cover (Fig. 4). The base of the exposed profile is characterised by a $>2 \mathrm{~m}$-thick mottled zone predominantly composed of kaolinite and includes cm-thick mottles that contain minor amounts of hematite (Figs. 4, 5E). The mottled zone evolves above into a red latosol, characterised by a relative increase in the proportion of hematite, which homogeneously stains the kaolinitic matrix. The red latosol evolves upwards into a $30-50 \mathrm{~cm}$ thick horizon of brown latosol. The brown latosol is then overlain by a transported detrital cover, characterised by a poorly consolidated limonitic matrix and containing numerous clasts of heterogeneous size and nature. These include angular quartz, pisolitic bauxite, vesicular and massive duricrust clasts, together with millimetric to multi- 
centimetric pyrite crystals transformed into goethite (Figs. 4 and 5A-5D). Subhorizontal, $\mathrm{cm}$ to dm-thick quartz \pm pyrite veins cut the mottled zone and the red latosol. These veins exhibit intense dismantling, thus contrasting with the relatively well-preserved veins observed in the mottled zone of the Achman Giraud profile (Fig. 5E). Together with the greater thickness of the mottled zone, this suggests that the weathering profile is more evolved at the Lupe site compared to the Achman Giraud site.

\section{Whole-rock geochemistry}

The Achman Giraud site was sampled for whole-rock geochemistry as the profile exhibits a greater diversity of weathering horizons. Biplots of Th, $\mathrm{Hf}, \mathrm{Ta}, \mathrm{TiO}_{2}, \mathrm{Fe}_{2} \mathrm{O}_{3}$ and $\mathrm{Al}_{2} \mathrm{O}_{3}$ against $\mathrm{Zr}$ concentrations are shown in Figure 6, and variations of major oxide and trace element concentrations along the main vertical transect (P1) in Figure 7. Results of major and trace element compositions of collected samples are summarised in Table 1. The unweathered amphibolite, collected along a nearby stream, displays a dioritic composition (TAS diagram; Middlemost, 1994) with $\mathrm{SiO}_{2}, \mathrm{Al}_{2} \mathrm{O}_{3}, \mathrm{Fe}_{2} \mathrm{O}_{3}$ and $\mathrm{CaO}$ contents of approximately 60, 15, 7 and 6 wt.\%, respectively. $\mathrm{MgO}, \mathrm{Na}_{2} \mathrm{O}, \mathrm{P}_{2} \mathrm{O}_{5}, \mathrm{~K}_{2} \mathrm{O}$ and $\mathrm{TiO}_{2}$ contents are below 3 wt.\%. Compared to the parent amphibolite, samples from the weathering profile exposed at Achman Giraud exhibit systematic changes in major and trace element compositions. Elements may be classified into three groups depending on their behaviour. Group 1 includes Fe, Ti, Zr, Hf, Th and Ta. These elements were nearly immobile during weathering and display increasing concentrations upwards in the profile (Figs. 6 and 7). High Field Strength Elements (HFSE) such as $\mathrm{Zr}$, Hf, Ta and Th show strong positive correlations and co-enrichments throughout the weathering profile, suggesting that they represent the least-mobile elements derived from a chemically homogeneous parent rock (Fig. 6). It is worth noticing that the bedrock sample, collected at a certain distance from the weathering profile, fits in the HFSE correlation trends but yields slightly higher HFSE concentrations than one saprolite sample (Fig. 6). Therefore, it is suggested that the weathering profile exposed at the Achman Giraud site derives from a protolith that is not entirely equivalent yet chemically similar to the sampled unweathered amphibolite. Poorly mobile elements, including $\mathrm{Fe}$ and $\mathrm{Ti}$, whose concentrations globally increase throughout the profile $\left(\mathrm{Fe}_{2} \mathrm{O}_{3}\right.$ from 7 to $12 \mathrm{wt} . \%$, $\mathrm{TiO}_{2}$ from 0.6 to $\left.1.0 \mathrm{wt} . \%\right)$, show similar enrichment patterns to those of the least mobile elements (Figs. 6 and 7). Nevertheless, significant dispersion from the correlation trends is observed in $\mathrm{Fe}_{2} \mathrm{O}_{3}$ vs $\mathrm{Zr}$ and $\mathrm{TiO}_{2} \mathrm{vs} \mathrm{Zr}$ biplots (Fig. 6), suggesting that Fe and Ti were slightly remobilised during weathering. Group 2 elements include $\mathrm{Al}, \mathrm{Si}$ and most of the analysed trace elements $(\mathrm{Pb}, \mathrm{Cu}, \mathrm{Zn}, \mathrm{Mn}, \mathrm{Ni}, \mathrm{Co}, \mathrm{Cr}$, 
Bi), which were significantly redistributed within the profile during weathering. Contrasting with $\mathrm{SiO}_{2}$, which remains relatively constant (around 60 wt.\%) throughout the profile, $\mathrm{Al}_{2} \mathrm{O}_{3}$ increases upwards from the bedrock. It reaches maximum concentrations of about $25 \mathrm{wt} . \%$ in the saprolite and the lower portion of the red latosol. Above, $\mathrm{Al}_{2} \mathrm{O}_{3}$ concentrations slightly decrease down to $15-20 \mathrm{wt} . \%$. Although these elements were residually enriched in the profile, they appear miscorrelated with least and poorly mobile elements (e.g. $\mathrm{Al}_{2} \mathrm{O}_{3}$ vs $\mathrm{Zr}$ in Fig. 6), supporting the assumption that they were significantly remobilised. Group 3 represents elements that were largely removed from the weathering profile, including $\mathrm{MgO}, \mathrm{Na}_{2} \mathrm{O}, \mathrm{P}_{2} \mathrm{O}_{5}$, $\mathrm{CaO}, \mathrm{K}_{2} \mathrm{O}$ and $\mathrm{Ba}$. Nevertheless, the depletion of $\mathrm{Mg}$ and $\mathrm{K}$ in the saprolite zone remains less pronounced than that of other mobile cations. There, $\mathrm{Mg}$ and $\mathrm{K}$ may have been temporally preserved from leaching, being in stable mineral phases such as smectite and white mica, respectively. In addition, the LOI increase from $1 \mathrm{wt} . \%$ in the bedrock to about $10 \mathrm{wt} . \%$ along the profile is related to the increasing content in newly-formed clays and oxy-hydroxides.

\section{Gold grade variation}

Variations of gold grades (Fig. 8) have been investigated along the vertical profile P1 and the two lateral profiles $\mathrm{P} 2$ and $\mathrm{P} 3$, i.e., from the Au-bearing quartz vein outwards. Whole-rock gold grades range from 0.03 to $7.14 \mathrm{ppm}$ along the P1 profile (Fig. 8A), with three samples grading above 2 ppm: one sample collected at the hanging wall of the Au-bearing quartz vein (grading $5.38 \mathrm{ppm}$ ) and two samples collected in the upper part of the weathering profile (at the top of the red latosol and within the brown latosol, grading 4.89 and $7.14 \mathrm{ppm}$, respectively). The vein itself was not analysed to avoid the nugget effect as mm large gold flakes are observed within the vein. Both lateral profiles realised within the red latosol (P2 profile, Fig. 8B) and mottled zone (P3 profile, Fig. 8C) exhibit a decrease in gold concentration from the Au-bearing quartz vein outwards. On the P2 profile, the gold grade decreases from 1.1 to $<0.1 \mathrm{ppm}$ within the first $30 \mathrm{~cm}$ from the vein edge. Similarly, on the P3 profile, the gold grade falls from 0.6 to $<$ $0.2 \mathrm{ppm}$ within the first $20 \mathrm{~cm}$ from the vein edge. No sample located farther than $1.5 \mathrm{~m}$ from the vein returns gold grade above the detection limit $(0.005 \mathrm{ppm})$. Whole-rock gold grades (Table 2) must be considered with caution as the sampled quantity was limited (up to $3 \mathrm{~kg}$ per sample), and the nugget effect may be significant.

\section{The paragenetic sequence at the Achman Giraud profile}

The amphibolitic bedrock is mainly composed of amphibole and plagioclase, in association with quartz, chlorite, ilmenite and magnetite (Fig. 9A), whereas the Au-bearing quartz vein 
contains minor euhedral pyrite and white mica. In the saprolite horizon, kaolinite represents the predominant mineral phase with up to $50 \mu \mathrm{m}$-large sheeted grains, possibly developed after amphibolite grains (Fig. 9B) and thin sticks in the matrix (Fig. 9C). Locally, hematite forms at the expense of coarse kaolinite along grain borders and within kaolinite sheets or crystallise as micrometric crystals in the matrix porosity. Millimetre-large gibbsite veins are locally observed within the saprolite (Fig. 9B). In the mottled zone, segregation of Fe leads to the formation of hematite-bearing mottles within a kaolinitic matrix that is essentially devoid of iron oxides (Fig. 9D, E, F). The contact between mottles and the kaolinite matrix is usually sharp (Fig. 9F, G). In the mottles, hematisation of kaolinite is well-developed along grain borders and within kaolinite sheets (Fig. 9H). In the iron-bearing mottles and the kaolinite matrix, quartz grains appear mostly unaffected by mottle development. The iron-bearing mottles exhibit a depletion in $\mathrm{Al}$ and $\mathrm{Ti}$ compared to the kaolinite matrix, together with enrichments in $\mathrm{Fe}$, as well as $\mathrm{Cr}$ concentration along mottle edges (Fig. 9D, E). In the red latosol, a significant portion of preexisting coarse kaolinite grains appear almost entirely replaced by hematite (Fig. 9J, K), and fine-grained hematite also develops within the kaolinitic matrix (Fig. 9K). In the brown latosol, hematite is mainly transformed into goethite, and the matrix is composed of kaolinite +/goethite and hematite (Fig. 9L). The global iron oxide content further increases at the expense of kaolinite. Throughout the weathering profile, only a few pre-existing mineral phases remain resistant to weathering, most notably quartz, ilmenite, zircon and rare magnetite. Samples collected proximal and distal from the primary quartz vein display a relatively similar abundance of residual quartz grains (Fig. 9A, G), suggesting that quartz grains inherited from the protolith dominates the global quartz budget in the profile. The persistence of quartz grains in the red and brown latosols, i.e., above the primary quartz vein, confirms this hypothesis. Nevertheless, the occurrence of unaltered pyrite inclusions within some of the quartz grains in the red latosol (Fig. 9J) suggests that additional quartz \pm pyrite veins may have been present in the upper part of the profile. Such veins underwent complete replacement of pyrite crystals by goethite throughout the weathering profile (Fig. 11I). The presence of oxidised pyrite crystals within the profile is thus interpreted to result from the dismantlement of either quartz \pm pyrite veins or pyrite-rich alteration haloes. Goethitised pyrite locally contains gold inclusions as described below.

\section{Supergene alteration of pyrite and associated in situ gold inclusions}

The supergene alteration of pyrite crystals within the Achman Giraud profile is associated with progressive changes in crystal textures (Fig. 10). Unweathered, subhedral to euhedral pyrite 
crystals are rarely observed in the saprolite horizon (Fig. 10G), as most of the crystals are already replaced by massive fine-grained goethite (Fig. 10E, D, B). In the saprolite and the red latosol, the rims of goethitised pyrite crystals commonly exhibit colloform textures with significant micro-porosity, resulting from dissolution and recrystallisation of goethite. The colloform goethite rims incorporated $\mathrm{Si}$ and $\mathrm{Al}$ at the expense of $\mathrm{Fe}$.

Micron-scale Au-inclusions are observed within the goethitised pyrite, both within grain cores and within the colloform rims (Fig. 10). Some micro-fractures within goethitised pyrite are locally filled with gold inclusions (Fig 10C and F), suggesting that the formation of gold microinclusions is related to supergene alteration. Nevertheless, although no fresh pyrite containing gold micro-inclusions were identified, the relative timing between gold precipitation and pyrite replacement by goethite remains unclear. Consequently, the hypogene or supergene nature of gold inclusions cannot be deciphered from textural observations alone. In the brown latosol, pyrite grains replaced by goethite exhibit extensive dissolution features throughout the entire grains (Fig. 10A). Although the brown latosol yields elevated gold grades up to $6 \mathrm{ppm}$, no gold micro-inclusions have been identified within goethitised pyrite originating from this horizon. Gold micro-inclusions are pure and do not bear any other metal in detectable amounts.

At the Lupe site, cm-scale oxidised detrital pyrite crystals (Fig. 11A) collected in the transported horizon contain unweathered pyrite cores and macroscopic porosity, indicating unachieved supergene alteration (Fig 11B). There, goethite exhibits characteristic boxwork textures with boxwork strips consisting of massive, Te-bearing goethite (up to $\sim 2 \mathrm{wt} \% \mathrm{Te}$ ) and locally containing electrum inclusions up to $200 \mu \mathrm{m}$ large (with Ag contents ranging from 29,3 wt.\% to $35 \mathrm{wt} . \%$ ) as well as dusty, micrometric to sub-micrometric Bi inclusions (Fig. 11C-11J). Infill material of the boxwork consists of Te-free, tabular goethite aggregates associated with micro-porosity (Fig. 11C, D).

\section{Morphology and geochemistry of free gold grains}

At Achman Giraud, visible gold grains located within quartz veins are associated with pyrite and quartz grains and display angular and irregular shapes and outlines with no porous surfaces (Fig. 12). Panned grains sampled within the saprolite and the mottled zone horizons similarly exhibit irregular shapes with typical textures of tabular gold crystal intergrowths and interlocked quartz relicts (Fig 12A, B, C and D). In addition, distinct micrometre-high sharp terraces (Fig. 12B) are observed on the surface of grains from the saprolite. At the same time, 
micrometric subcircular dissolution pits with striation and micro-globules of secondary gold are visible on the surface of grains from the mottled zone (Fig. 12D).

Panned grains collected within the overlying red latosol also exhibit irregular shapes and outlines with moderately blunt edges, together with jagged rims, flaky structures, and inverse prints of dissolved quartz and pyrite crystals (Fig. 12F and G). Although similar in shape, gold grains from the red latosol differ from the grains collected in the underlying horizons. They display, more frequently, dissolution pits (Fig. 13F, G and H) and five $\mu$ m-thick spherulitic overgrowths of secondary gold on grain surface (Fig. 13E).

Contrastingly, in the Lupe profile, gold grains were only recovered from the uppermost $20 \mathrm{~cm}$ of the latosol horizon and the transported cover. All panned grains are rounded to subrounded with strongly blunt surfaces, and some exhibit transportation marks, mechanical scratching, and etching features (Fig 13). EPMA X-ray maps (Fig. 14) and spot analysis (Fig. 15 and Table 3) conducted on representative free gold grains from both sites indicate that $\mathrm{Ag}$ is the only detectable element apart from $\mathrm{Au}$. However, traces of $\mathrm{Cu}, \mathrm{Pd}, \mathrm{Cd}$ and $\mathrm{Pt}$ were also detected from LA-ICP-MS analysis (Table 4). All the analysed free gold grains from Achman Giraud collected in the saprolite, the mottled zone and the red latosol are chemically homogeneous regarding Ag and Au contents (Fig. 14A, B and C). These yield Ag contents ranging from 1.5 to 7 wt.\% depending on the analysed grain (Fig. 15) together with $\mathrm{Cu}$ and $\mathrm{Pd}$ concentrations of 200 to $1000 \mathrm{ppm}$ and 0.2 to $1 \mathrm{ppm}$, respectively. Contrastingly, all the analysed grains from Lupe, collected in the brown latosol and the transported cover, exhibit 5 to $20 \mu \mathrm{m}$-large outer rims depleted in $\mathrm{Ag}$ (below 2.7 wt.\%) and relatively homogeneous cores (from 6.4 to 9.8.wt. $\%$, depending on the analysed grain), with sharp contact between both (Fig. 14D, E and Fig. 15). Free gold grains from Lupe also yield trace $\mathrm{Cu}$ concentrations (200-400 ppm) and Pd with contents between 0.1 and $1.2 \mathrm{ppm}$. The $\mathrm{Cu}$ content of gold grains is lower at Lupe (200-400 ppm) than at Achman Giraud (up to $1000 \mathrm{ppm}$ ).

\section{Discussion}

Styles, timing and controls on supergene processes at Couriège 
The succession of weathering horizons exposed in the Achman Giraud and Lupe profiles results from the combination of in situ weathering, erosion and pedimentation processes related to the regolith landform regimes in which they are situated (Anand et al., 2019; Butt 2015; Chardon et al., 2018). The saprolite horizon is only exposed in the Achman Giraud profile. The preservation of the primary rock fabric unequivocally testifies a purely residual (i.e., not transported) inheritance. Goethite replaces primary pyrite in the saprolite, e.g. at the weathering front near the bedrock-saprolite interface, as proposed by Girard et al. (1997). The nature of the overlying mottled zone and latosol horizons, i.e., in situ or remobilised, is more difficult to apprehend, as primary textures are almost destroyed. Although it cannot be excluded that material transported over a weathering profile may be subsequently weathered to develop mottle textures, the upwards evolution from the saprolite to the mottled clay zone (see Fig. 3D) is primarily typical of in situ deep weathering. Such textures are thus produced by the bleaching of primary lithostructure and local segregation of Fe (Tardy et al., 1991; Ghosh \& Guchhait, 2015). It is worth noticing that the formation of the mottles seems also accompanied by the segregation of other elements, most notably the preferential incorporation of $\mathrm{Cr}$ along mottle edges and the depletion of $\mathrm{Ti}$ in the mottles (Fig. 9G). Also, quartz vein relics that persist in the mottled and latosol zones, the absence of stone lines, and the progressive transition between the successive horizons indicate that latosol and mottled horizons do not derive from transported material. The latosol still displays a significant amount of Si and Al, which may be considered residual of the mottled zone/saprolite but not as a derivate from a dismantled lateritic residuum. As illustrated in the conceptual model in Figure 16, the latosol formation can be interpreted as being syn- to post-erosion, with the latosol blanketing the whole area. The absence of a transported cover indicates that in situ weathering and erosion regimes dominate over deposition regime. Further support for the autochthonous character of the entire profile is provided by the collinear increase of immobile element ( $\mathrm{Zr}, \mathrm{Hf}, \mathrm{Th}, \mathrm{Ta})$ concentrations from the unweathered amphibolite to the brown latosol. Such increase is produced by the leaching and loss of most highly mobile cations (including $\mathrm{Mg}, \mathrm{Na}, \mathrm{Ca}, \mathrm{K}$ and $\mathrm{Ba}$ ) under the intense chemical weathering typical of tropical environments (Freyssinet et al., 2005). Regarding textures, the goethite replacing pyrite remains preserved throughout the profile with only minor dissolution/recrystallisation features developed at the grain edges, except in the uppermost brown latosol where goethite is largely recrystallised, as previously described at the Yaou deposit by Girard et al. (2000). 
At Lupe, the autochthonous latosol overlying the mottled zone contains elevated amount of quartz and kaolinite, arguing that it formed at the expense of the mottled zone as proposed at Achman Giraud. The overlaying detrital horizon results from the dismantlement, transport and redeposition of quartz vein and duricrust material situated initially at a higher elevation. Transport distance was probably short as quartz and duricrust clasts are angular and up to 15 cm-large. Considering (i) the situation of the Lupe site, i.e. on the lower slope portion of the Lupe hill, which represents the highest relief of the prospect, (ii) the presence of a lateritic residuum locally observed on the hilltop, (iii) the orientation of the red latosol - the transported cover interface that is subparallel to the present-day local slope and (iv) the proximal to intermediate nature of transported clasts, it is, therefore, most likely that the detrital cover at the Lupe site comes directly from uphill. Such interpretation suggests that the source of the gold-bearing detrital pyrite is also situated uphill at a moderate distance from the sampling site. Furthermore, the transportation and deposition of the transported cover are considered relatively recent because it overlies an already mature weathering profile as supported by the intense dismantlement of the quartz vein within the thick and well-developed mottled zone. In addition, goethite replacement of detrital pyrite is frequently incomplete. Therefore, erosion to redeposition of the transported cover observed at the Lupe site may postdate both the abandonment of the S1 weathering surface and the subsequent planation/duricrust formation episodes. The relative timing between deposition of the pediment cover and latosolisation remains equivocal. Although the base of the transported horizon exhibits undisputable evidence for an erosional contact sharply truncating the brown latosol, the matrix of the transported cover is highly similar to the brown latosol material. This may suggest that the deposition of the transported cover predates or is coeval to the latosol formation. In such a scenario, the latosol would have developed through both the transported material and the underlying, autochthonous weathering horizons.

\section{Effects of deep weathering on gold distribution, grades and styles}

In supergene environments, residual enrichment, chemical dissolution/reprecipitation, and physical transport are the main processes involved in gold redistribution (Freyssinet et al., 2005). According to Webster and Mann (1984), the style and intensity of gold mobilisation depend on the climate, the bedrock composition, and geomorphological factors. Therefore, the 
distribution of gold grades in the investigated profiles, together with the compositional and morphological characteristics of gold, allows to assess the mobility of gold during weathering.

The Achman Giraud site provides the opportunity to assess the extent of gold redistribution in a residual deep weathering profile developed after a mineralised quartz vein and its host rock. It is established that, within weathering profiles developed in equatorial settings, the chemical dispersion of gold only occurs in the lateritic residuum and the upper portion of the mottled zone, whereas dispersion in the saprolite remains very narrow (Freyssinet et al. 2005; Butt, 2015). Such a model cannot be fully tested at the Achman Giraud site as the uppermost portion of the weathering profile is not preserved. Yet, our investigations support the lack of lateral dispersion of gold (Fig. 8B and C) in the saprolite, the mottled zone and the lower portion of the red latosol. Indeed, gold anomalies are only observed within a few tens of centimeters from the mineralised veins. Such observations argue either for a limited migration of the gold away from the primary source, or even no migration, as gold enrichment close to Au-veins is commonly observed in orogenic lode gold deposits (Dubé \& Gosselin, 2007). On the other hand, it is interesting to note that two samples from the upper red latosol and brown latosol show elevated gold contents ( $>5 \mathrm{ppm})$ but are not spatially associated with the vein. It is suggested that these uppermost latosol horizons could have developed from the upper portion of the mottled zone, in which a dispersion halo was developed. In such a scenario, gold dispersion may have been sourced from another mineralised vein situated above and now entirely dismantled.

The angular morphology, the Au-Ag contents (average fineness of 971) and the Au-Ag homogeneous distribution in free gold grains from the saprolite to the latosol argue that these grains are primary and inherited from the hypogene mineralisation. Such grains underwent moderate dissolution-reprecipitation, expressed through (i) the increasing presence of circular pits on surfaces and irregular shapes following gold dissolution after exposure to weathering solutions as already shown elsewhere by several authors (Colin et al., 1989; Colin \& Vieillard, 1991; Colin et al., 1993; Bamba et al., 2002; Larizzatti et al., 2008) and (ii) the rare occurrences of secondary (Au2) gold spherolites on surfaces of primary (Au1) gold grains (Fig. 12E), similar to the description of Bamba et al. (2002). It is worth mentioning that, according to Freyssinet et al. (1987), secondary gold overgrowths can be destroyed by panning. Therefore, the number of observations of Au2 is not a quantitative proxy of the amount of secondary gold. Santosh 
and Omana (1991) also describe fine secondary grains in cavities of panned grains, but such features have not been observed at Couriège. On the opposite, gold micro-inclusions in the altered pyrite crystals from the saprolite to the red latosol are Ag-free (average calculated fineness of 998; Fig. 10) and result probably from the dissolution of primary gold and reprecipitation (Freyssinet \& Butt, 1988; Hough et al., 2011) during the supergene pseudomorphosis of pyrite by goethite. Although a supergene signature is supported by the high gold fineness (Mann, 1984; Butt, 1989; Freyssinet et al., 2005; Larizzatti et al., 2008), it remains unclear whether these inclusions formed during weathering or were already present in pyrite and subsequently depleted in Ag during weathering. The presence of hypogene gold inclusions in unweathered pyrite is common in many orogenic gold deposits, forming the bulk of the gold mineralisation associated with quartz-carbonate veining (e.g., Combes et al., 2021 and references therein).

Together with the lack of lateral gold dispersion from the vein, the primary character of large gold grains and the restricted evidence for secondary gold precipitation argue for a limited influence of supergene processes in the chemical redistribution of gold through the exposed profile, with no clear evidence for supergene enrichment or dispersion. The lack of any significant supergene enrichment can be explained by (1) the weak dismantlement of quartz veins, with gold grains remaining trapped within veins, (2) a poorly developed alteration halo along Au-bearing veins, with, therefore, a minor amount of gold remobilised in the host-rock, and (3) a limited residual enrichment due to the retention of $\mathrm{Si}$ within the profile. Such observations are similar to that of Bowell et al. (1992) at Ashanti in Ghana, where lateral dispersion of gold is lacking and explained by a limited migration of the Au-complexes and local dissolution/re-precipitation processes.

At the Lupe site, gold grains were observed only in the transported cover and within the uppermost $20 \mathrm{~cm}$ of the autochthonous latosol. Rounded grains with transportation marks demonstrate the involvement of physical transport processes. Moreover, the gold grains collected within the upper brown latosol also exhibit some physical transport features. Although this horizon is interpreted as autochthonous, it is suggested that mechanical mixing between the transported cover and the underlying latosol may have affected the uppermost $20 \mathrm{~cm}$ of the brown latosol. The transported gold grains then physically contaminated the barren latosol. The main geochemical characteristic of rounded grains collected at Lupe is the presence of Ag-poor rims (average fineness of 933 and up to $997 \mathrm{ppm}$ in grain cores and rims, respectively), 
indicative of Ag removal and pure gold reprecipitation (Butt \& Zeegers, 2015). Such Agdepleted rims are expected within the upper horizons of the profiles as previously reported elsewhere by Colin et al. (1989), Freyssinet et al. (1989), Colin \& Vieillard (1991), Bamba et al. (2002), Larizzatti et al. (2008), Falconer \& Craw (2009), and Vishiti et al. (2015) among others. According to Gray et al. (1992), "a possible explanation is that the rims are the consequence of galvanic reactions on the electrum surface involving the simultaneous solution of $\mathrm{Ag}^{+}$and $\mathrm{Au}^{+}$ions, the immediate replating of $\mathrm{Au}$ onto the electrum surface and the $\mathrm{Ag}$ leached as solution species such as $\mathrm{Ag}^{+}$or $\mathrm{AgCl}_{2}{ }^{-"}$. Contrastingly, the chemical homogeneity and the low average fineness (680 ppm) of the large (up to $200 \mu \mathrm{m}$ ) electrum inclusions hosted by cm-large detrital pyrite grains suggest a primary origin. Nevertheless, the association of these electrum inclusions with Bi dusty inclusions and Te-rich goethite along boxwork textures in the pyrite raises questions about the potential effect of goethitisation on the remobilisation of gold and associated metals. As for its detrital nature, gold at Lupe is interpreted to be spatially sourced from quartz \pm pyrite veins likely situated uphill on the Lupe hill (Fig. 2), following physical transport. Whereas the zonation of free gold grains suggests that they underwent significant weathering during or after transport, the absence of zonation in pyrite-hosted electrum grains and the incomplete goethitisation of pyrite suggest a limited effect of weathering on the detrital pyrite. Such observations may indicate multiple sources of gold in the transported cover, including (i) material exposed long enough to weathering to produce rims on gold grains and (ii) material freshly exposed to weathering where pyrite replacement by goethite and Ag leaching from electrum grains are lacking or incomplete. To summarise, the $\mathrm{Au}-\mathrm{Ag}$ content variations observed at Couriège are shown in Figure 15. The different types of gold grains show variable composition from electrum to Ag-bearing gold and testify to the effects of supergene processes such as dissolution and gold refinement. It is worth noting that our investigations focus on visible gold but do not provide constraints on the potential contribution of invisible gold to the gold budget, in particular in the primary pyrite and its goethitised supergene counterpart. Nevertheless, it has been suggested that gold sorption is much less efficient on goethite than on pyrite so that goethite is unlikely to host significant amounts of invisible gold, contrasting with pyrite (Schoonen et al., 1992).

Therefore, this study confirms the lack of significant chemical dispersion of gold in the mottled zone and saprolite at the macroscopic scale (Fig. 8) but reveals, at the microscopic scale, the effect of chemical supergene processes resulting in the formation of $5 \mu \mathrm{m}$ large spherolite of secondary gold or Ag-depleted supergene gold micro-inclusions in goethite. From the results and interpretations of the multi-disciplinary approach used in this study, a three-phase 
conceptual model is proposed (Fig. 16), involving (i) an early stage of deep weathering and peneplenation, (ii) subsequent dismantlement, transport and deposition of the weathering material (iii) a later latosol development, affecting both the transported and autochthonous uppermost horizons. This model, which accounts for the diversity of gold expressions, encompasses both the supergene chemical processes (e.g., Ag-depletion, dissolution of hypogene gold grain) and the physical remobilisation processes with regards to the local geomorphological context.

\section{Implications for gold exploration}

Gold exploration in weathered and covered terrains commonly relies on analysing surface or shallowly collected soil samples that may or may not have a direct genetic relationship with the underlying basement. Comprehensive characterisation of the regolith landscape is required, especially regarding the relictual, erosional or depositional nature of the regolith surface (Butt et al., 2000; Arhin and Nude, 2009; Chardon et al., 2018; Sawadogo, 2020). The distinction between in situ and transported material within deep weathering profiles may rely on several types of observation at different scales. Careful investigation of the relative geomorphic position and lateral extension of landscape elements distinguishes residual, erosional and depositional contexts. When exposed, iron duricrusts may prove helpful for geochemical vectoring as the formation of lateritic residuum may lead to gold remobilisation and enrichment (Anand et al., 2019). Such an approach requires discriminating purely residual duricrusted surfaces (lateritic residuum; Anand et al., 2002) from duricrusts developed on glacis (ferricrete; Anand et al., 2002; Chardon et al., 2018; Sawadogo et al., 2020) through field-based investigations, including regolith mapping and textural observations.

Investigations conducted on the truncated, in situ deep weathering profile at Achman Giraud highlight no significant dispersion of gold from the mineralised veins in saprolite and lower mottled horizons, although the dispersion may be more pronounced in the overlying residual latosol. In such a context where the lateritic residuum is absent, soil sampling conducted on latosols developed directly after the saprolite or the lower portion of the mottled zone may not prove useful as broad dispersion haloes are unlikely to be identified. On the other hand, the inheritance of latosol horizons is usually challenging to assess, and gold anomalies in latosols that are entirely or even partly developed after transported material may lead to false positives and spurious genetic relationships with underlying horizons. Furthermore, the usefulness of pathfinder elements such as $\mathrm{Pb}, \mathrm{Cu}, \mathrm{As}, \mathrm{Bi}, \mathrm{Te}$, and $\mathrm{Ag}$ needs to be better assessed as they may 
positively correlate with $\mathrm{Au}$ (Anand \& Butt, 2010; Sunkari et al., 2019). Nonetheless, at Couriège, $\mathrm{Au}$ is not associated with other metals, although the elevated $\mathrm{Au}$ and $\mathrm{Bi}$ grades in some samples from Achman Giraud latosol may suggest a primary association. In all cases, the minimisation of the nugget effects requires to sample significant rock volumes.

In transported-covered profiles, such as the Lupe site, gold surficial enrichment does not indicate buried mineralisation (false positive, Fig. 16). Still, it derives from one or several sources located at higher elevations in the paleo-landscape that prevailed during their transport. With surface/soil sampling, the reconstruction of landscape chronology may prove helpful in targeting the source of gold anomalies in transported covers and identify false negative and false positive responses at the surface. The morphological and chemical characteristics of transported clasts and gold grains may also provide information on the proximal or distal character of the source. At Lupe, the presence of large and angular clasts and the relative preservation of detrital pyrite suggest a relatively proximal gold source, whereas the presence of rounded and Ag-depleted gold rather suggests an intermediate to distal gold source. This discrepancy, which may result from either multiple sources or a differential alteration of the transported material, highlight that the evaluation of the proximal to the distal character of transported covers may be challenging.

\section{Conclusions}

This study investigates the style and distribution of gold mineralisation in two deep weathering profiles at the Couriège prospect, French Guiana. First, the Achman Giraud profile consists of an in situ autochthonous profile exposed from the saprolite to the latosol, wherein the primary gold mineralisation is associated with sigmoidal quartz \pm pyrite veins. There, vertical and lateral gold grade distribution demonstrates a weak dispersion of gold not extending farther than 30 $\mathrm{cm}$ from the Au-bearing vein into the weathered host rock. No clear evidence of supergenerelated enrichment was found, but dispersion is more pronounced in the residual latosol. Gold is observed as (i) free primary gold grains, with increasing dissolution features in the upper horizons together with rare secondary (supergene-related) spherolitic gold overgrowths of high fineness, and (ii) in situ supergene micro-inclusions of high fineness within goethitised pyrite crystals. Secondly, the Lupe profile consists of a gold-bearing detrital horizon truncating a barren weathering profile. The size and angular nature of transported clasts suggest a proximal to an intermediate source. Within this horizon, gold is present as (i) free gold grains displaying 
sub-rounded shapes, mechanical transportation marks on surfaces as well as Ag-depleted rims resulting from supergene leaching of silver, and (ii) primary electrum inclusions within $\mathrm{cm}-$ large, partly goethitised pyrite crystals, in association with Bi dusty inclusions and Te-goethite. Therefore, a complex distribution of gold types within the two profiles is shown, witnessing primary differences in composition (from electrum to Ag-bearing gold), supergene chemical modifications (dissolution, refinement of gold, secondary gold formation) and mechanical concentration in transported horizons. The identified gold grades agree with Voicu et al. (2001), stating that average gold grades within bedrock- to saprolite-hosted orebodies range between 1.3 and $2.3 \mathrm{~g} / \mathrm{t}$ Au for most gold deposits of the Guiana Shield.

This study highlights that physical supergene processes complicate gold exploration in equatorial settings, through the dismantlement of shallow chemical haloes and the formation of transported gold anomalies. Comprehensive gold targeting based on soil sampling must be combined with field-based observations to consider the residual vs transported nature and the inheritance of the sampled material. In particular, occurrences of transported gold anomalies must be identified, as these are not indicative of underlying mineralisation but may help to trace back an original gold source upslope.

\section{Acknowledgements}

This study is part of Vincent Combes's PhD research at the Université de Lorraine within the GeoRessources laboratory in Nancy, France. We are grateful to D. Chardon for his constructive comments, O. Rouer and A. Lecomte at the SCMEM and A. Flammang for thin sections manufacturing at the GeoRessources laboratory Nancy, France. In addition, we gratefully acknowledge D. Craw and one anonymous reviewer for their constructive comments that helped to improve the manuscript significantly and R. Chapman for editing work and comments.

\section{Funding}

This research was funded by Auplata Mining Group (AMG) and benefited from the framework of the CREGU. 


\section{References}

Anand, R.R., Paine, M., 2002. Regolith geology of the Yilgarn Craton, Western Australia: implications for exploration. Aust. J. Earth Sci. 49, 1-163.

Anand, R. R., Smith, R. E., Paine, M. D., 2002. Genesis, classification and atlas of ferruginous materials, Yilgarn Craton. Australian Mineral Industries Research Association. \& CRC LEME (Australia).

Anand, R.R., Butt, C.R.M., 2010. A guide for mineral exploration through the regolith in the Yilgarn Craton. Aust. J. Earth Sci. 57, 1015-1114.

Anand, R.R., Hough, R.M., Salama, W., Aspandiar, M.F., Butt, C.R.M., Gonzalez-Alvarez, I., Metelka, V., 2019. Gold and pathfinder elements in ferricrete gold deposits of the Yilgarn Craton of Western Australia: a review with new concepts. Ore Geol. Rev. 104, 294-355.

Arhin, E. and P.M. Nude, 2009. Significance of regolith mapping and its implication for gold exploration in Northern Ghana: A case study at Tinga and Kunche. Geochem. Explor. Env. A., 9, 63-69.

Bamba, O., Parisot, J.C., Grandin, G., Beauvais, G., 2002. Ferricrete genesis and supergene gold behaviour in Burkina Faso, West Africa. Geochem. Explor. Environ. Anal. 2, 3-14.

Benedetti, M., Boulegue, J., 1991. Mechanism of Au transfer and deposition in a supergene environment. Geochim. et Cosmochim Ac. 55, 1539-1547.

Bowell, R.J., Foster, R.P., Gize, A.P., 1993. The mobility of gold in tropical rain forest soils. Econ. Geol. 88, 999-1016.

Butt, C.R.M. and Smith, R.E. (Compilers and Editors), 1980. Conceptual models in exploration geochemistry, 4: Australia. J Geochem Explor. 12: 89-365 
Butt, C.R.M., 1989. Genesis of supergene gold deposits in the lateritic regolith of the Yilgarn Block, Western Australia. In: In: Keays, R.R., Ramsay, W.R.H., Groves, D.I. (Eds.), The Geology of Gold Deposits: The Perspective in 1988 8. Econ Geol. Monograph, 460-470.

Butt, C.R.M., 1998. Supergene gold deposits. AGSO J. Geo. Geophys. 17, 89-96.

Butt, C.R.M., Lintern, M., Anand, R.R., 2000. Evolution of regoliths and landscapes in deeply weathered terrain - implications for geochemical exploration. Ore Geol. Rev. 16, 167-183.

Butt, C.R.M., Zeegers, H. (Eds.), 2015. Regolith Exploration Geochemistry in Tropical and Subtropical Terrains Handbook of Exploration Geochemistry 4. Elsevier, Amsterdam (607 pp.).

Butt, C.R.M., 2015. The Development Of Regolith Exploration Geochemistry In The Tropics And Sub-Tropics. Ore Geol Rev. 73, 10.1016

Chardon, D., Grimaud, J.L., Beauvais, A., Bamba, O., 2018. West African lateritic pediments: landform-regolith evolution processes and mineral exploration pitfalls. Earth Sci. Rev. 179, $124-146$.

Carignan, J., Hild, P., Mévelle, G., Morel, J., Yeghicheyan, D., 2001. Routine analyses of trace elements in geological samples using flow injection and low pressure on-line liquid chromatography coupled to ICP-MS: a study of reference materials BR, DR-N, UB-N, AN-G and GH. Geostandards Newsletter 25, 187-198.

Chardon, D., Grimaud, J.-L., Beauvais, A., Bamba, O., 2018. West African lateritic pediments: landform-regolith evolution processes and mineral exploration pitfalls. Earth- Sci. Rev. 179, 124-146.

Colin, F., Lecomte, P., Boulange, B., 1989. Dissolution feature of gold particles in a lateritic profile at Dondo Mobi, Gabon. Geoderma 45, 241-250.

Colin, F., and Vieillard, P., 1991, Behavior of gold in lateritic equatorial environment: Weathering and surface dispersion of residual gold particles at Dondo Mobi, GabonJ Appl Geochem. 6, 279-290. 
Colin, F., Vieillard, P., and Ambrosi, J. P., 1993, Behavior of gold in lateritic equatorial environment: Mass transfer and thermodynamic study. Earth and Planetary Sci. Lett. 114, 269285

Combes, V., Eglinger, A., Andre-Mayer, A-S., Teitler, Y., Heuret, A., Gibert, P., Béziat, D., Polyphase gold mineralisation at the Yaou deposit, French Guiana. Accepted at the Geological Society London Special Publication.

Costa M.L., Costa J.A.V., Angélica R.S. 1993. Gold bearing bauxitic laterite in a tropical rain forest climate: Cassiporé, Amapá, Brazil. Chronique de la Recherche Minière, 510, 41-51.

Costa, L.M., 1993. "Gold distribution in lateritic profiles in South America, Africa and Australia: applications to geochemical exploration in tropical regions. J. Geochem. Explor. 47, 143-163.

Craw, D., MacKenzie, D., P., Grieve, 2015. Supergene gold mobility in orogenic gold deposits, Otago Schist, New Zealand. N. Z. J. Geol. Geophys. 58 (2), 123-136.

Craw, D., Kerr, G., 2017. Geochemistry and mineralogy of contrasting supergene gold alteration zones, southern New Zealand. J Appl Geochem. 85:19-34.

Daoust, C., Voicu, G., Brisson, H. and Gauthier, M., 2011, Geological setting of the Paleoproterozoic Rosebel gold district, Guiana Shield, Suriname. J South Am Earth Sci. 32, 222-245.

Dardenne, M.A., Schobbenhaus, C., 2003. Metallogeny of the Guiana Shield. Geol. Fr. 2-4, 291-319.

Delor, C., Lahondère, D., Egal, E., Lafon, J.-M., Cocherie, A., Guerrot, C., Rossi, P., Truffert, C., Théveniaut, H., Phillips, D., Avelar, V.G.d., 2003b. 2-3-4 In: Transamazonian crustal growth and reworking as revealed by the 1:500000 scale geological map of French Guiana. Géol Fr, 5-57. 
Delor, C., de Roever, E.W.F., Lafon, J.-M., Lahondère, D., Rossi, P., Cocherie, A., Guerrot, C., Potrel, A., 2003a. The Bakhuis ultrahigh-temperature granulite belt (Suriname) : II. Implications for late Transamazonian crustal stretching in a revised. Géol Fr. 2-3- 4, 207-230.

Dubé, B., and Gosselin, P., 2007, Greenstone-hosted quartz-carbonate vein deposits, in Goodfellow, W.D., ed., Mineral Deposits of Canada: A Synthesis of Major Deposit-Types, District Metallogeny, the Evolution of Geological Provinces, and Exploration Methods: Geological Association of Canada, Mineral Deposits Division, Special Publication No. 5, 4973.

Eglinger A., André-Mayer A.-S., Combes V., Teitler Y., Heuret A., 2020. Les gisements d'or de la Guyane française. Géologues 206 :36-40.

Falconer, D., Craw, D., 2009. Supergene gold mobility: a textural and geochemical study from gold placers in southern New Zealand. Econ Geol. Special Publication 14, 77-93.

Franklin, J., Bertoni, C., Boudrie, M., Bout, J., Costelloe, D., Lillie, F., Millo, L., Sauvage, J., 2000. The Paul Isnard gold-copper occurrence, French Guiana: the first volcanogenic massive sulphide occurrence in the Guiana Shield? In: Sherlock, R., Logan, M.A.V. (Eds.), VMS Deposits of Latin America, Geological Association of Canada, Mineral Deposits Division. Special Publication, pp. 509-542

Freyssinet, P., Zeegers, H. and Tardy, Y., 1987. N6oformation d'or dans les cuirasses latéritiques : dissolution, migration, pr6cipitation. C.R. Acad. Sci., 305 (II): 867-874.

Freyssinet, Ph., Butt, C.R.M., 1988. Morphology and geochemistry of gold in a lateritic profile, Bardoc Mine, Western Australia. Restricted Report, MG 59R. CSIRO Australia, Division of Exploration Geoscience, Perth, pp. 19

Freyssinet, Ph., Lecomte, P., Edimo, A., 1989. Dispersion of gold and base metals in the Mborguene laterite profile. J. Geochem. Explor. 32, 99-116.

Freyssinet, Ph., 1993. Gold dispersion related to ferricrete pedogenesis as South Mali: Application to geochemical exploration. Chron Rech Min. 510, 25-40. 
Freyssinet, P., Itard, Y., 1997. Geochemical Mass Balance of Gold Under Various Tropical Weathering Conditions: Application to Exploration, In "Proceedings of Exploration 97: Fourth Decennial International Conference on Mineral Exploration” edited by A.G. Gubins, 347-354

Freyssinet, Ph., Butt, C.R.M., Morris, R.C., Piantone, P., 2005. Ore-forming processes related to lateritic weathering. In: Hedenquist, J.W., Thomson, J.F.H., Goldfarb, R.J., Richards, J.P. (Eds.), Economic Geology 100th Anniversary Volume, Econ Geol. 681-722

Freyssinet, P., Farah, A., 2000. Geochemical mass balance and weathering rates of ultramafic schists in Amazonia. Chem Geol.170, 133-151.

Girard, J.-P., Razanadranorosoa, D., Freyssinet, P., 1997. Laser oxygen isotope analysis of weathering goethite from the lateritic profile of Yaou, French Guiana: paleoweathering and paleoclimatic implications. Appl. Geochem. 12, 163- 174.

Girard J.-P., Freyssinet P., and Chazot G., 2000. Unravelling climatic changes from intraprofile variation in oxygen and hydrogen isotopic composition of goethite and kaolinite in laterites: An integrated study from Yaou, French Guiana. Geochim. et Cosmochim Ac. 64, 409-426

Ghosh, S., Guchhait, S., 2015. Characterisation and evolution of primary and secondary laterites in northwestern Bengal Basin, West Bengal, India. Jof Palaeogeography. 4, 203 -230.

Gray, D.J., Butt, C.R.M., Lawrance, L.M., 1992. The geochemistry of gold in lateritic terrains. In: Butt, C.R.M., Zeegers, H. (Eds.), Regolith Exploration Geochemistry in Tropical and Subtropical Terrains. Handbook of Exploration Geochemistry, 4. Elsevier, Amsterdam, pp. $461-482$.

Guiraud, J., Tremblay, A., and Jebrak, M., 2017, The Rhyacian Montangne d'Or auriferous volcanogenic massive sulphide deposit, French Guiana, South America: Stratigraphy and geochronology [ext. abs.]: Society for Geology Applied to Mineral Deposits, 14th Biennial Meeting, Québec City, August 20-23, 2017, Extended Abstracts, p. 237-240. 
Guiraud, J., Tremblay, A., Jébrak, M., Ross, P-S., Lefrançois, R., 2020. Stratigraphic setting and timing of the Montagne d'Or deposit, a unique Rhyacian Au-rich VMS deposit of the Guiana Shield, French Guiana, Precambr. Res. 337, 105551.

Horbe, A.M.C., Martins-Ferreira, M.A.C., Lima, R.S., 2019. Supergene gold characterisation by geochemistry, grain morphology and $\mathrm{Au}-\mathrm{Ag}-\mathrm{Cu}-\mathrm{Te}$ classification. J. S. Am. Earth Sci. 95, 102315.

Hough, R., Noble, R., Reich, M., 2011. Natural gold nanoparticles. Ore Geol Rev. 42, 55-61

Kovacs, R., Schlosser, S., Staub, S., Schmiderer, A., Pernicka, E., Günther, D., 2009. CharacterisationCharacterization of calibration materials for trace element analysis and fingerprint studies of gold using LA-ICP-MS. J Anal At Spectrom. 24. 10.1039/b819685k.

Larizzatti, H., Oliveria, S.M.B., Butt, C.R.M., 2008. Morphology and composition of gold in a lateritic profile, Fazenda Pison "Garimpo", Amazon, Brazil. J. S. Am. Earth Sci. 25, 359-376

Lafrance, J., Bardoux, M., Voicu, G., Stevenson, R., Machado, N., 1999. Geological and metallogenic environments of gold deposits of the Guiana Shield; a comparative study between St-Elie (French Guiana) and Omai (Guyana). Explor. Min. Geol. 8, 117-135.

Ledru, P., Lasserre, J., Manier, E., Mercier, D., 1991. Le Proterozoique inferieur nord guyanais ; revision de la lithologie, tectonique transcurrente et dynamique des bassins sedimentaires. Bull Soc Geol Fr. 162, 627-636.

Mann, A.W., 1984. Mobility of gold and silver in lateritic weathering profiles, some observations from Western Australia. Econ Geol. 79, 38-49.

Marcoux, É., Milési, J.-P., 1993. Lead isotope signature of early Proterozoic ore deposits in western Africa; comparison with gold deposits in French Guiana. Econ. Geol. 88, 1862-1879.

Meyer, H., Cauzid, J., 2020. Hameye /MARCIA: MARCIA v 0.1.0. doi:10.5281/zenodo.3929745 
Middlemost E.A.K., 1994. Naming materials in magma/igneous rock system. Earth Sci Rev $37: 215-224$

Milési, J.-P., Egal, E., Ledru, P., Vernhet, Y., Thiéblemont, D., Cocherie, A., Tegyey, M., Martel-Jantin, B., Lagny, P., 1995. Les minéralisations du Nord de la Guyane française dans leur cadre géologique. Chron Rech Min. 518, 5-59.

Milesi, J., Lerouge C, Delór C, Ledru P, Billa M, Cocherie A, Egal E, Fouillac A, Lahondère D, Lasserre J, Marot A, Martel-Jantin B, Rossi P, Tegyey M, Théveniault H, Thiéblemont D, Vanderhaeghe, O., 2003. Gold deposits (gold-bearing tourmalinites, gold-bearing conglomerates, and mesothermal lodes), markers of the geological evolution of French Guiana: geology, metallogeny, and stable isotope constraints. Géol Fr, 2-3-4:257-290.

Patton, C., Hellstrom, J., Paul, B., Woodhead, J. Hergt, J., 2011. Iolite: freeware for the visualization and processing of mass spectrometry data. J. Anal. At. Spectrom. 26: 2508-2518.

Perera, W., Senanayake, Ga., Nicol, M., 2005. Interaction of gold(I) with thiosulfate-sulfite mixed ligand systems. Inorg Chim Acta. 358, 2183-2190.

Picot, J. C, Chevillard, M., 2015. Potentiel aurifère de la Guyane - Note de synthèse BRGM

Pokrovski, G., Akinfiev, N., Borisova, A., Zotov, A., Kouzmanov, K., 2014. Gold speciation and transport in geological fluids: Insights from experiments and physical-chemical modelling. 10.1144/SP402.4.

Santosh, M., Omana, P.K., 1991. Very high gold from lateritic weathering profiles of Nilambur, southern India. Geology 19, 46-749.

Sawadogo, B., Bamba, O., Chardon, D., 2020. Landform-regolith mapping in the West African context. Ore Geol Rev.126, 103782.

Schoonen, M.A.A., Fisher, N., Maryann, W., 1992., Gold sorption onto pyrite and goethite: A radiotracer study. Geochim Cosmochim Acta. 56, 1801-1814 
Sunkari, E. D., Appiah-Twum, M., Lermi, A. 2019, Journal of African Earth Sciences, 158, 103519

Tardy, Y., Kobilsek, B., Paquet, H., 1991. Mineralogical composition and geographical distribution of African and Brazilian periatlantic laterites: The influence of continental drift and tropical paleoclimates during the past 150 million years and implications for India and Australia. J Afr Earth Sci. 12(1-2): 283-295.

Tedeschi, M., Hagemann, S.G., Davis, J., 2018. The Karouni Gold Deposit, Guyana, South America: part I. Stratigraphic Setting and Structural Controls on Mineralization. Econ Geol. $113,1679-1704$

Théveniaut, H., Freyssinet, Ph.,2002. Timing of lateritization on the Guiana Shield: Synthesis of paleomagnetic results from French Guiana and Suriname. Palaeogeography, Palaeoclimatology, Palaeoecology. 178. 91-117.

Vanderhaeghe, O., Ledru, P., Thiéblemont, D., Egal, E., Cocherie, A., Tegyey, M., Milesi, JP., 1998. Contrasting mechanism of crustal growth: Geodynamic evolution of the Paleoproterozoic granite-greenstone belts of French Guiana. Precambrian Res. 92:165-193.

Velásquez, G., Béziat, D., Salvi, S., Siebenaller, L., Borisova, A.Y., Pokrovski, G.S., and De Parseval, P., 2014, Formation and deformation of pyrite and implications for gold mineralization in the El Callao district, Venezuela. Econ Geol. 109, 457-486.

Vishiti, A., Suh, C., Lehmann, B., Egbe, J.A., Shemang, E., 2015. Gold grade variation and particle microchemistry in exploration pits of the Batouri gold district, SE Cameroon. J Afr Earth Sci. 111. 1-13.

Voicu, G., Bardoux, M., Stevenson, R., 2001. Lithostratigraphy, geochronology and gold metallogeny in the northern Guiana Shield, South America: a review Ore Geol Rev. 18, 211236.

Webster, J. G.; Mann, A. W. 1984: The influence of climate, geomorphology and primary geology on the supergene migration of gold and silver. J. Geochem. Explor. 22, 21-42. 
Zotov, A., Kuzmin, N., Reukov, V., Tagirov, B., 2018. Stability of AuCl2- from 25 to $1000{ }^{\circ} \mathrm{C}$ at Pressures to 5000 bar and Consequences for Hydrothermal Gold Mobilization. Minerals. 8. 286. 


\section{Captions}

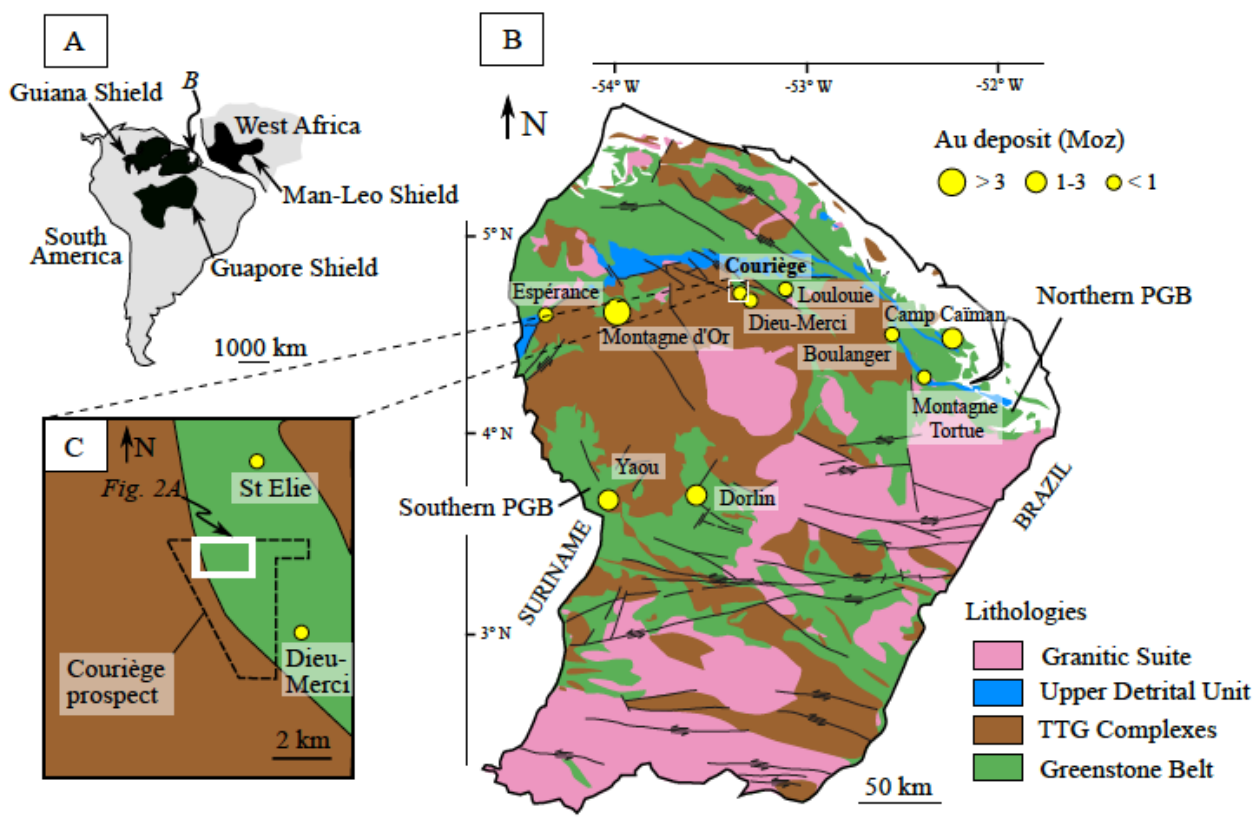

Fig 1

Fig. 1. (A). Simplified overview of the Precambrian shields located in South America and Western Africa, namely the Guapore Shield, the Man-Leo Shield and the Guiana Shield. (B). Map of simplified Palaeoproterozoic formations located in French Guiana (modified from Delor et al., 2003b; Eglinger et al., 2020). (C). Couriège prospect lithology map. The deposit is located at the contact between the northern Paramaca greenstone belt and the central TTG complex. 

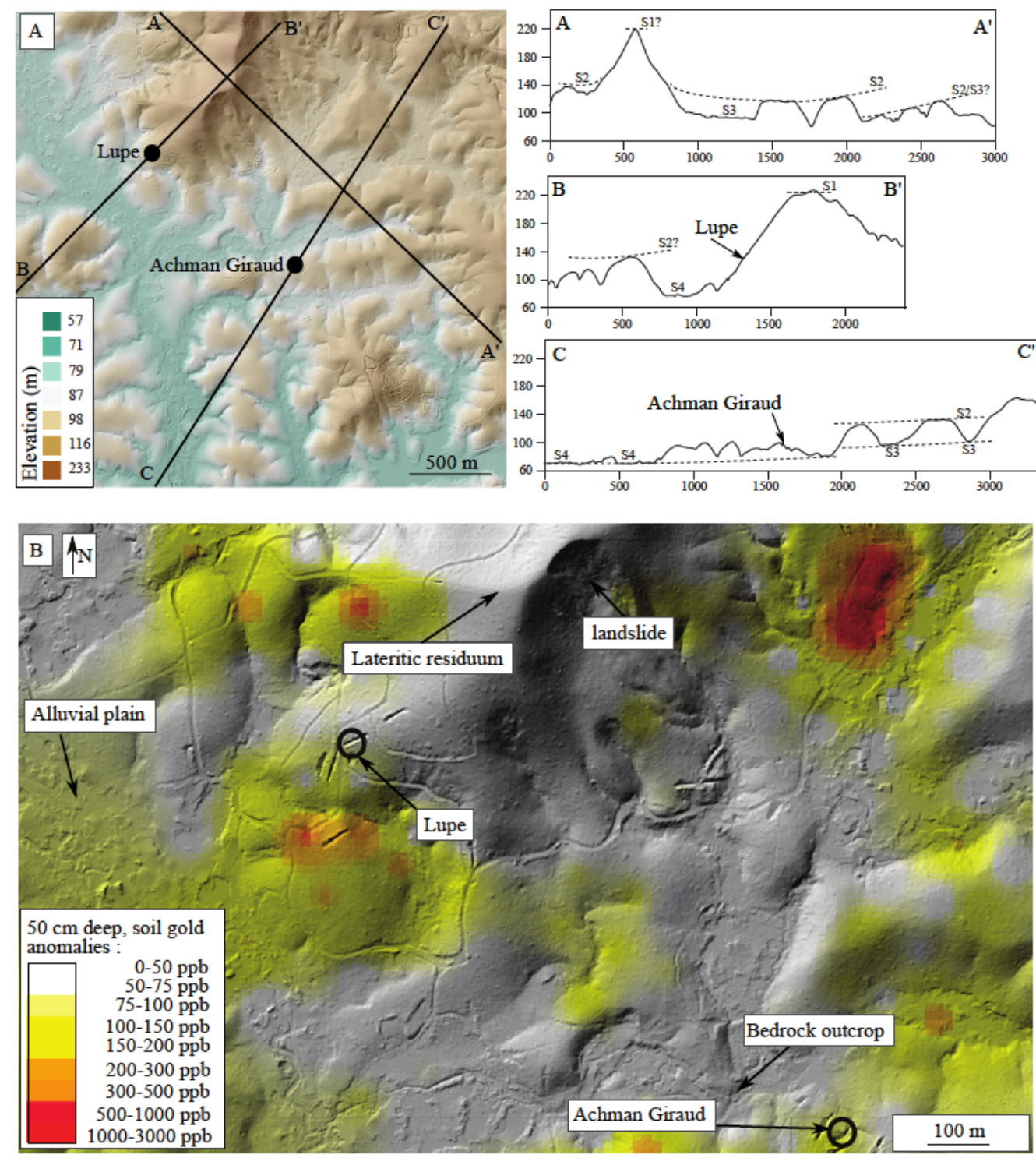

Fig. 2. (A). Digital Elevation Model of the NW part of the Couriège tenement with locations of the two studied sites (Achman Giraud and Lupe) and topographic profiles highlighting the geomorphology of the prospect characterised by moderate variations in elevation with dissected lateritic residuum plateaus, flattened hills, landslides, and alluvial plains. Interpreted surface S1: a relic of an old, now dismantled duricrusted surface, S2: top of flat hills representing remnants of lateritic plateaus (in situ) or ancient glacis surface, S3: the alluvial plain of an almost closed, kilometric watershed and S4: the main active alluvial plain. (B). Soil gold anomalies distribution in the studied area with locations of Lupe, Achman Giraud and the sampled bedrock outcrop. 

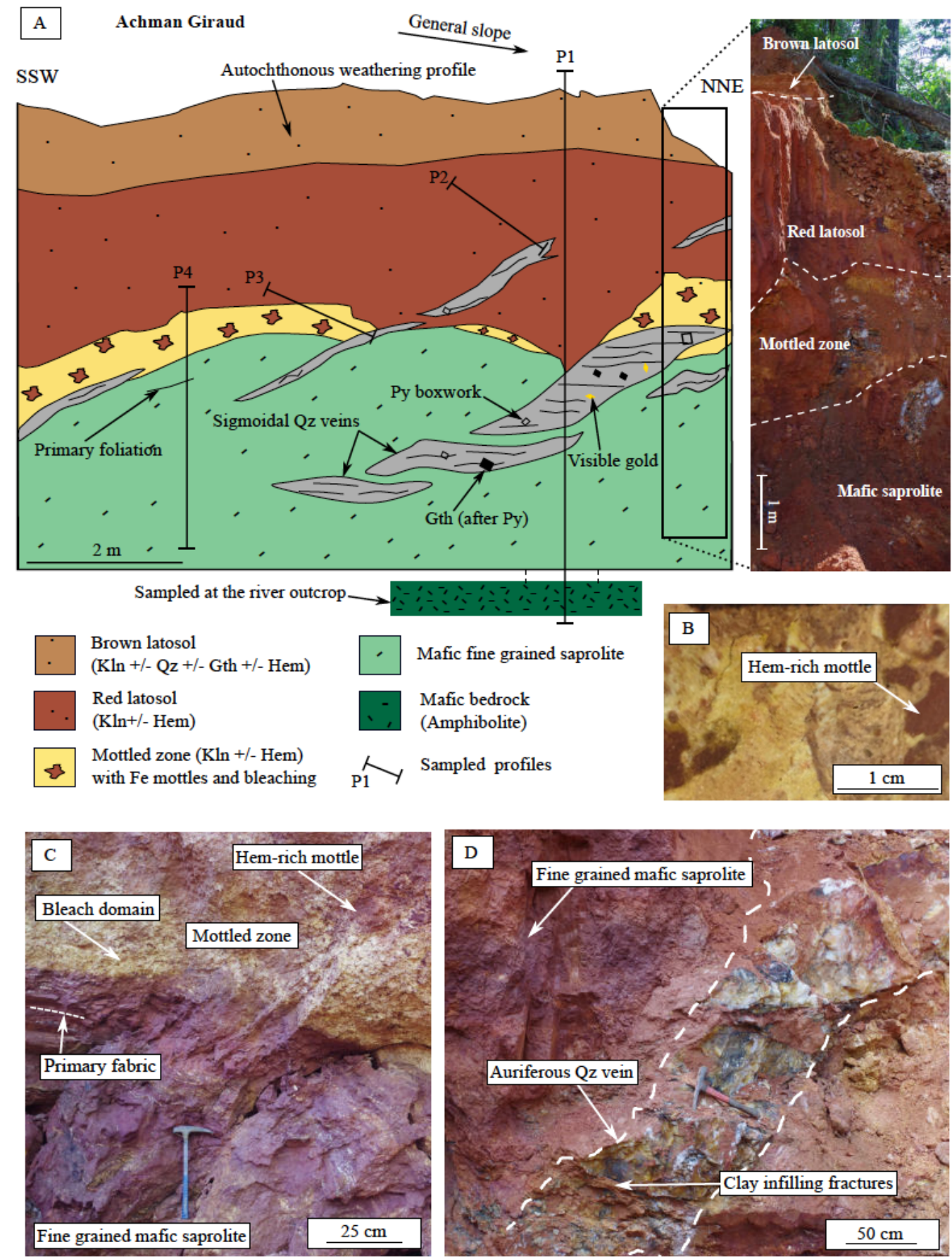

Fig. 3. (A). Schematic cross section of the Au-bearing regolith at the Achman Giraud site with location of sampled profiles. (B). Macroscopic photograph of the mottled zone. (C). Sharp contact between the fine grained mafic saprolite and the mottled zone. (D). Auriferous quartz vein within the saprolite horizon. (Abbreviations: $\mathrm{Qz}=$ quartz, $\mathrm{Amp}=$ amphibole, $\mathrm{Hem}=$ hematite, Kln=kaolinite, $\mathrm{Gth}=$ goethite, $\mathrm{Py}=$ pyrite). 

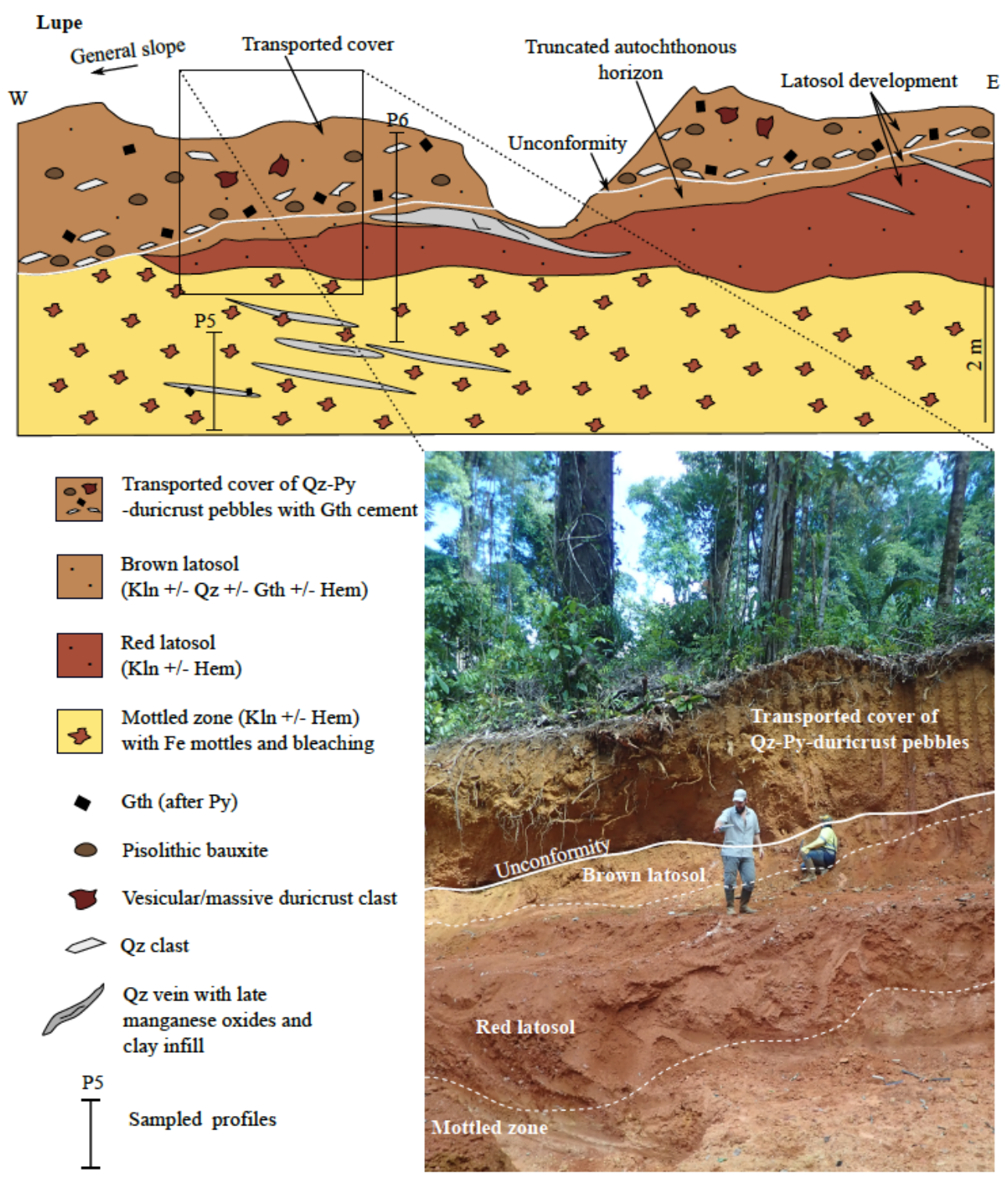

Fig. 4.

Schematic cross section of the Au-bearing regolith at the Lupe site with location of sampled profiles. (Abbreviations: Qz=quartz, Hem=hematite, Gth=goethite, Kln=kaolinite, $\mathrm{Py}=$ pyrite). 

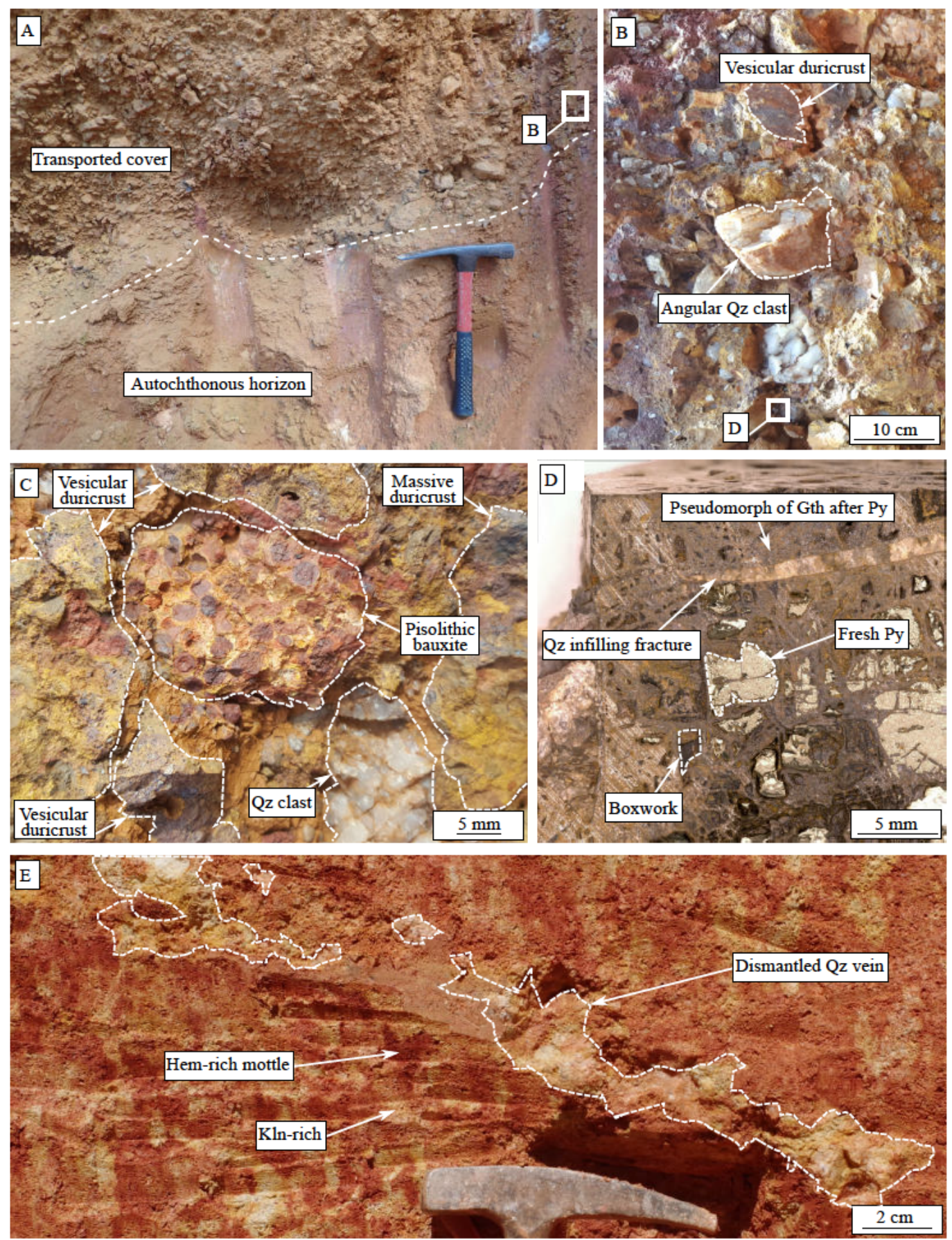

Fig. 5. Macroscopic photographs (A). Contact between the transported cover and the autochthonous horizon. (B). Zoom on the transported cover with vesicular duricrust clasts and angular quartz clasts. (C). Zoom in the transported cover displaying pisolithic bauxite, vesicular and massive duricrust clasts, and quartz clasts within a limonitic matrix. (D). Detrital goethitised pyrite located in (B). (E). Highly dismantled quartz vein within the mottled zone. (Abbreviations: Qz=quartz, Hem=hematite, Gth=goethite, Kln=kaolinite, $\mathrm{Py}=$ pyrite). 

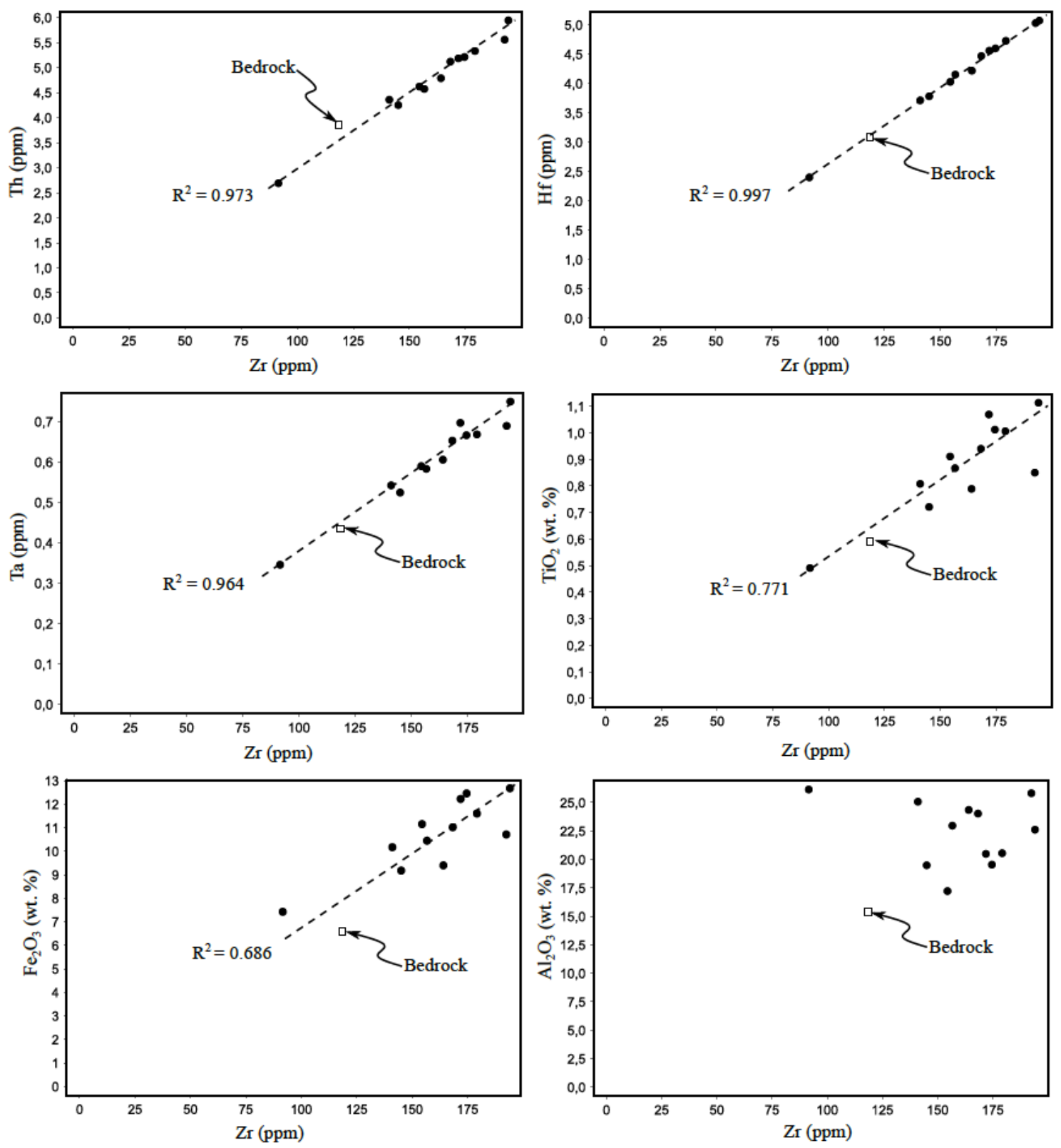

Fig. 6. Biplots of Th, Hf, Ta, $\mathrm{TiO}_{2}, \mathrm{Fe}_{2} \mathrm{O}_{3}$ and $\mathrm{Al}_{2} \mathrm{O}_{3}$ against $\mathrm{Zr}$, along the Achman Giraud profile. 

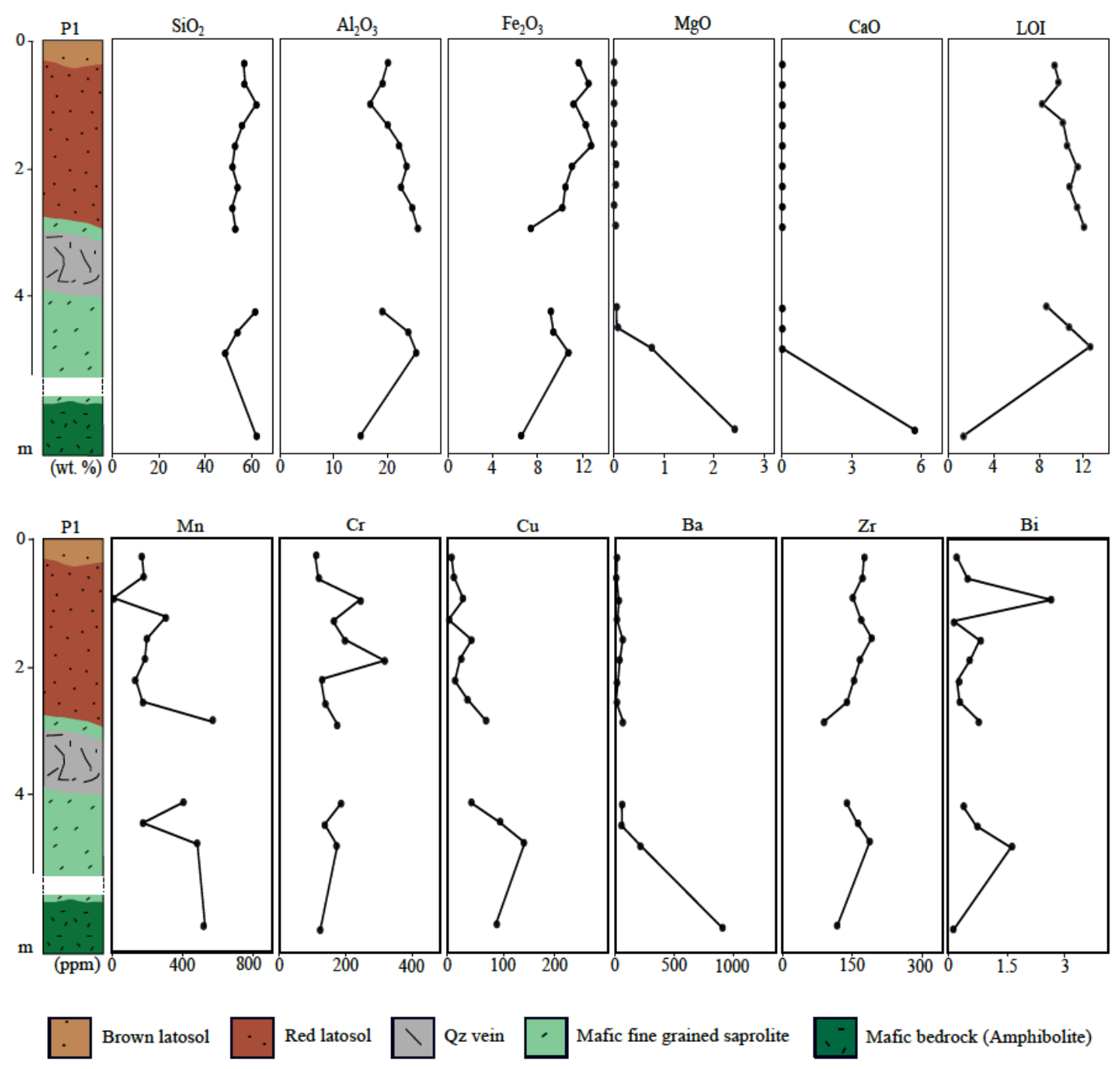

Fig. 7. Variations of major and trace element concentrations (wt.\% and ppm respectively) along depth in the P1 transect at Achman Giraud. 


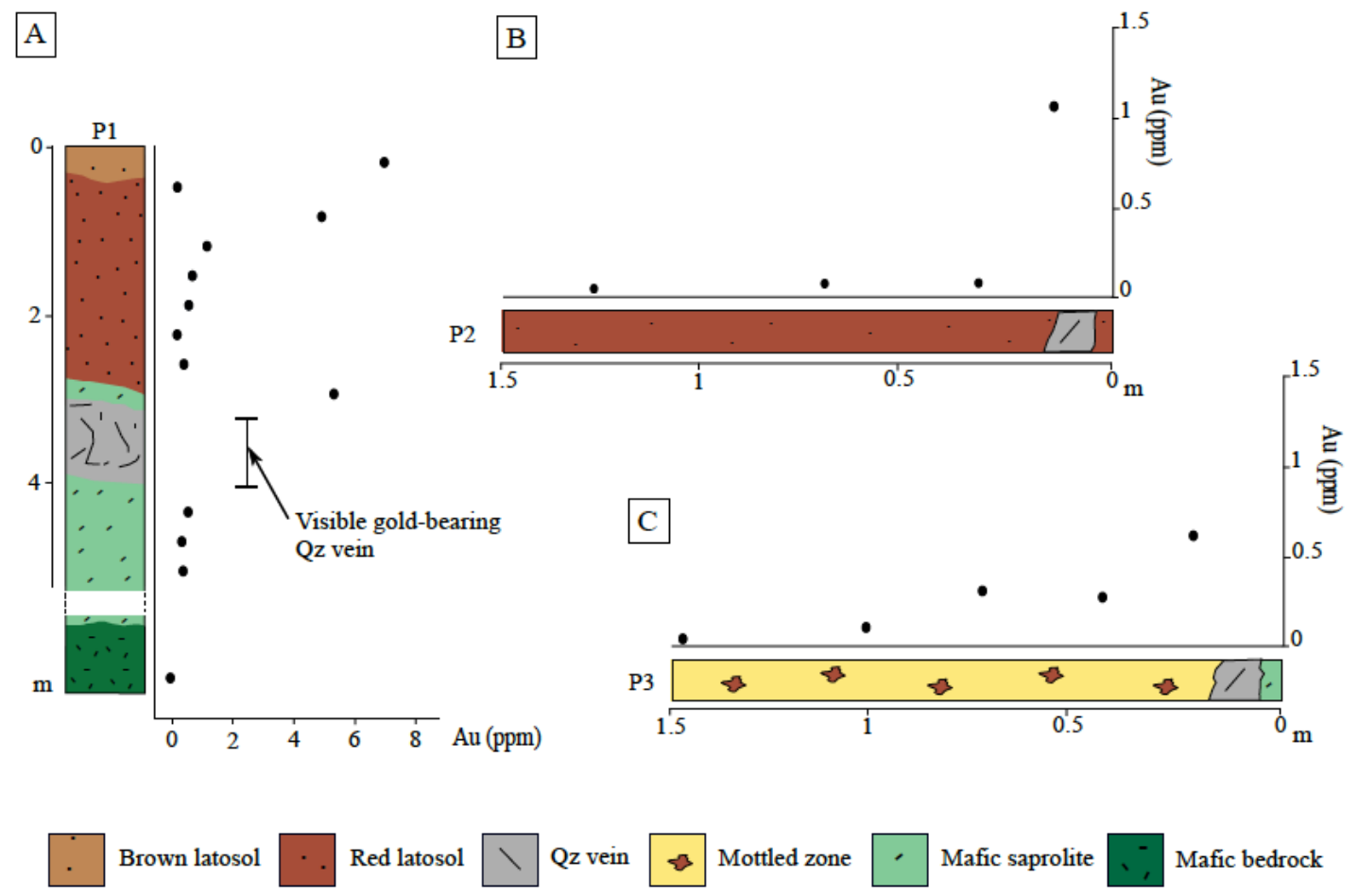

Fig. 8. (A). Variations of the whole-rock gold grade (ppm) along depth in the P1 transect. (B). Lateral variation of the whole-rock gold grade ( $\mathrm{ppm}$ ) along the P2 transect. (C). Lateral variation of the whole-rock gold grade ( $\mathrm{ppm})$ along the P3 transect. All data are from the Achman Giraud site. 

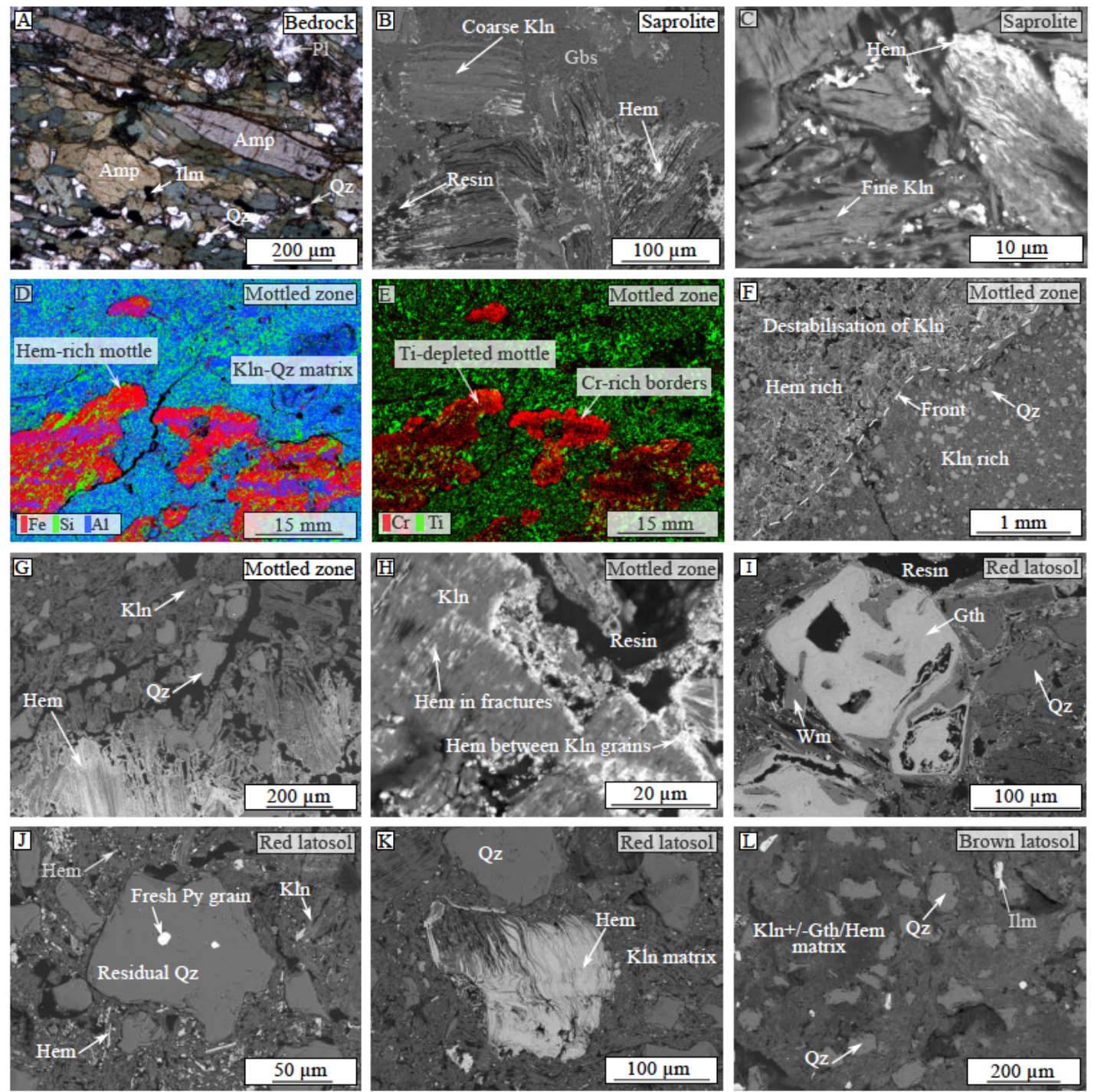

Fig. 9. BSE images (except for bedrock in optical microphotography) and $\mu$ XRF maps of typical mineral associations. (A). Amphibolite bedrock displaying amphibole, quartz, plagioclase and ilmenite crystals (B). Saprolite with typical coarse kaolinite grain and associated hematisation along kaolinite sheets and grain borders. (C). Partial replacement of kaolinite by hematite and formation of hematite within the porosity. (D). Fe-Si-Al $\mu$ XRF map highlighting Fe-rich mottles (red) within the kaolinitic Al-rich matrix (blue), together with quartz grains (green) displaying a discreet fabric present in both the mottles and the matrix. (E). Cr-Ti $\mu$ XRF map showing Ti-depleted mottles with Cr-rich margins (red). (F). Border of an iron-rich mottle within kaolinite matrix, with formation of hematite at the expense of kaolinite. (G). Zoom on the hematisation front associated with iron-rich mottles. $(\mathrm{H})$. Zoom on a Fe-mottle from the mottled zone, with hematite development in-between kaolinite sheets and around kaolinite grains. (I). Goethitised pyrite crystal interlocked with primary white mica in the red latosol. $(\mathrm{J})$. Residual quartz grain encapsulating a preserved fresh pyrite inclusion in the red latosol. (K). Complete hematisation of a coarse kaolinite grain within the red latosol and (L). Kaolinite and goethite/hematite-rich matrix in the brown latosol. (Abbreviations: Qz=quartz, $\mathrm{Ilm}=$ ilmenite, Amp=amphibole, Hem=hematite, Gbs=gibbsite, Kln=kaolinite, Py=pyrite). 


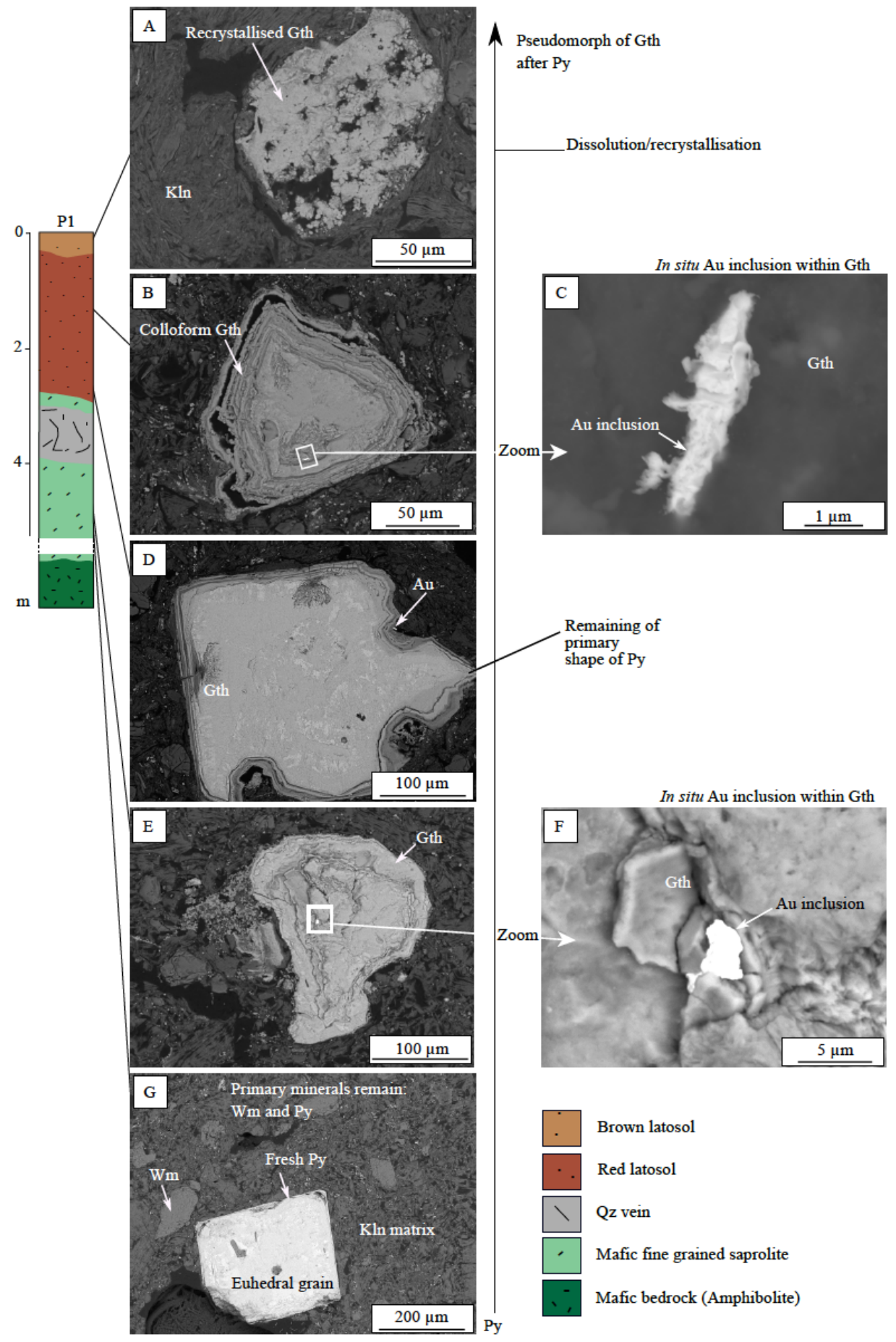

Fig. 10. Textural evolution of goethitised pyrite through the P1 transect with evidence for dissolution-reprecipitation of goethite (A, B, D, E, G) with examples of in situ gold microinclusions (C and F). (Abbreviations: Qz=quartz, Gth=goethite, Kln=kaolinite, Py=pyrite, $\mathrm{Wm}=$ white mica). 

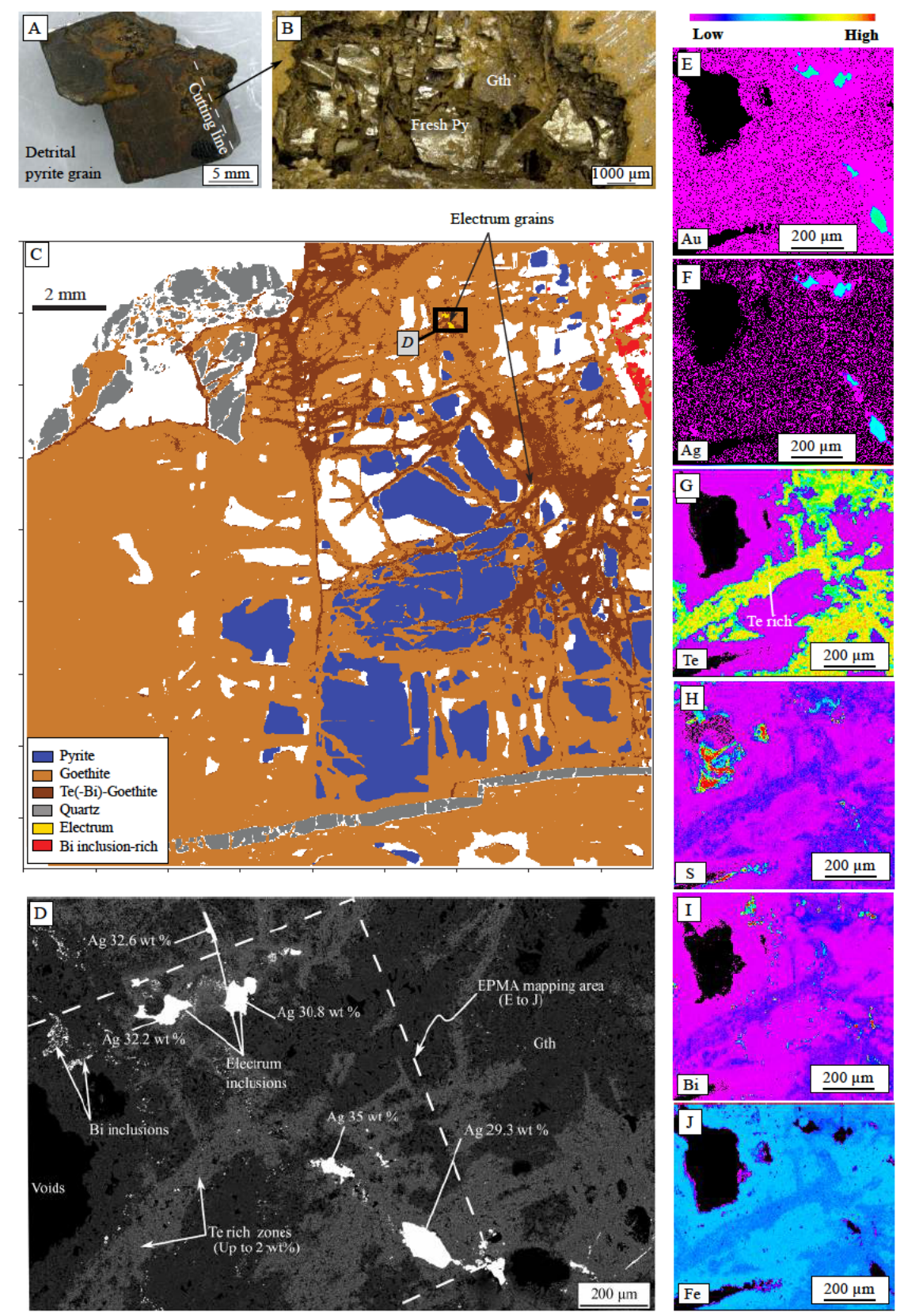

Fig. 11. (A). Overview of a detrital pyrite crystal from the transported cover of the Lupe site. (B). Macroscopic image of a half-cut pyrite crystal with fresh pyrite relics and partial goethite replacement. (C). Interpreted mineral map from $\mu \mathrm{XRF}$ data on the partly goethitised pyrite showing boxwork textures enriched in Te, together with electrum and Bi inclusions. (D). BSE image of the goethitised pyrite showing electrum micro-inclusions and Te-bearing goethite boxwork, together with in situ EPMA analyses of electrum micro-inclusions. (E-J). Au, Ag, Te, $\mathrm{S}$, Bi and $\mathrm{Fe} \mathrm{X}$-ray maps (EPMA) of the Au-Ag-Te-Bi-bearing goethitised pyrite. (Abbreviations: $\mathrm{Gth}=$ goethite, $\mathrm{Py}=$ pyrite). 


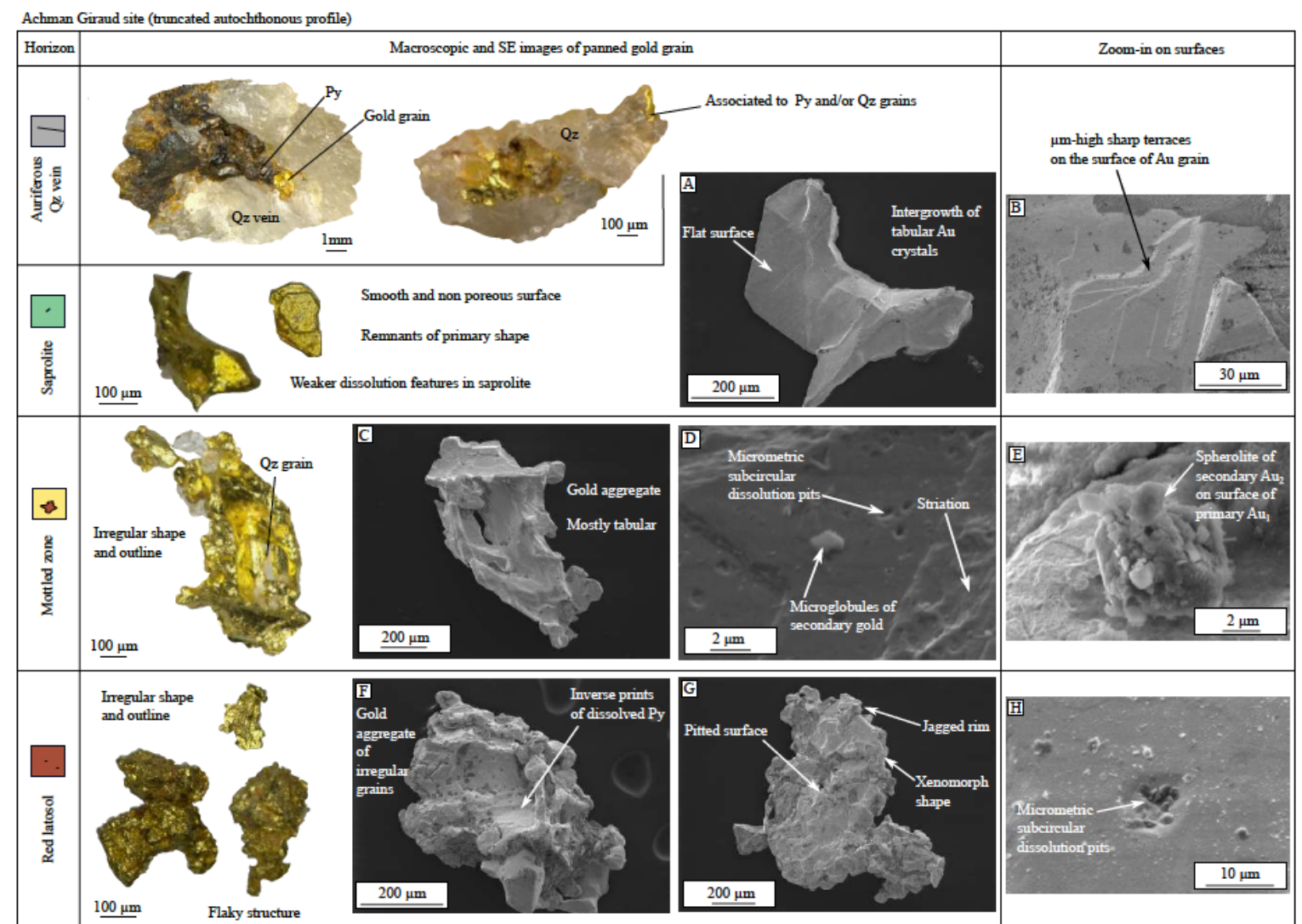

Fig. 12. Representative macroscopic images of panned gold grains from each studied horizon at the Achman Giraud site highlighting the main morphological characteristics of sampled grains. (A). Tabular grain sampled in saprolite. (B). Typical sharp terraces. (C). Gold aggregate from the mottled zone. (D). Zoom on subcircular dissolution pits and microglobules of secondary gold. (E). Spherolite of secondary gold. (F). Aggregate of irregularly shaped gold grains. (G). Xenomorph grain with pitted surface from the red latosol and (H). Zoom on a subcircular dissolution pit. 


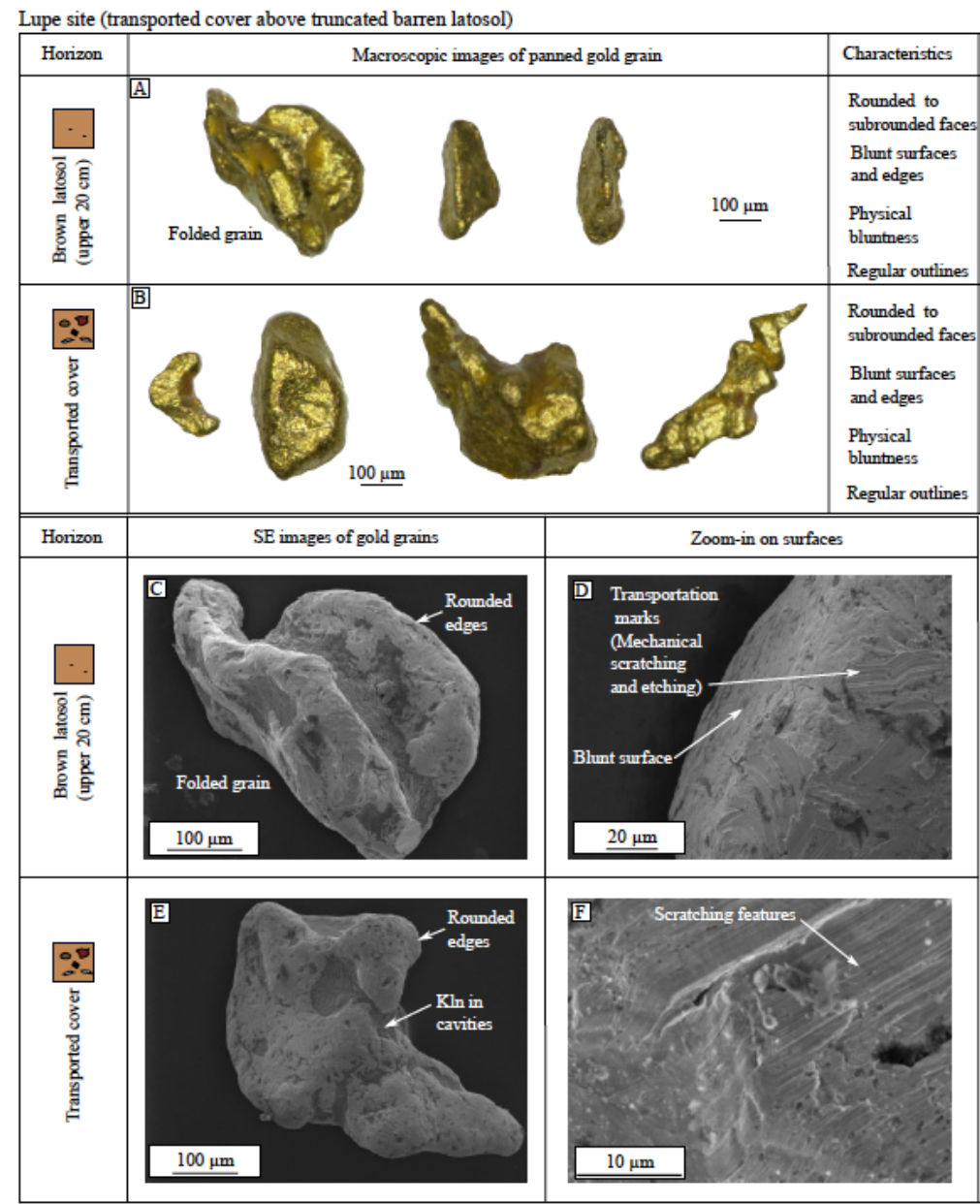

Fig. 13. Macroscopic images of grains from the Lupe site. (A). Upper $20 \mathrm{~cm}$ of the brown latosol. (B). Transported cover, with SE images (SEM) of (C). Rounded grain from the uppermost red latosol. (D). Rounded grain sampled in the same horizon displaying transportation marks. (E). Rounded grain displaying transportation marks from the detrital layer and (F) Scratching features on the grain shown in (E). 


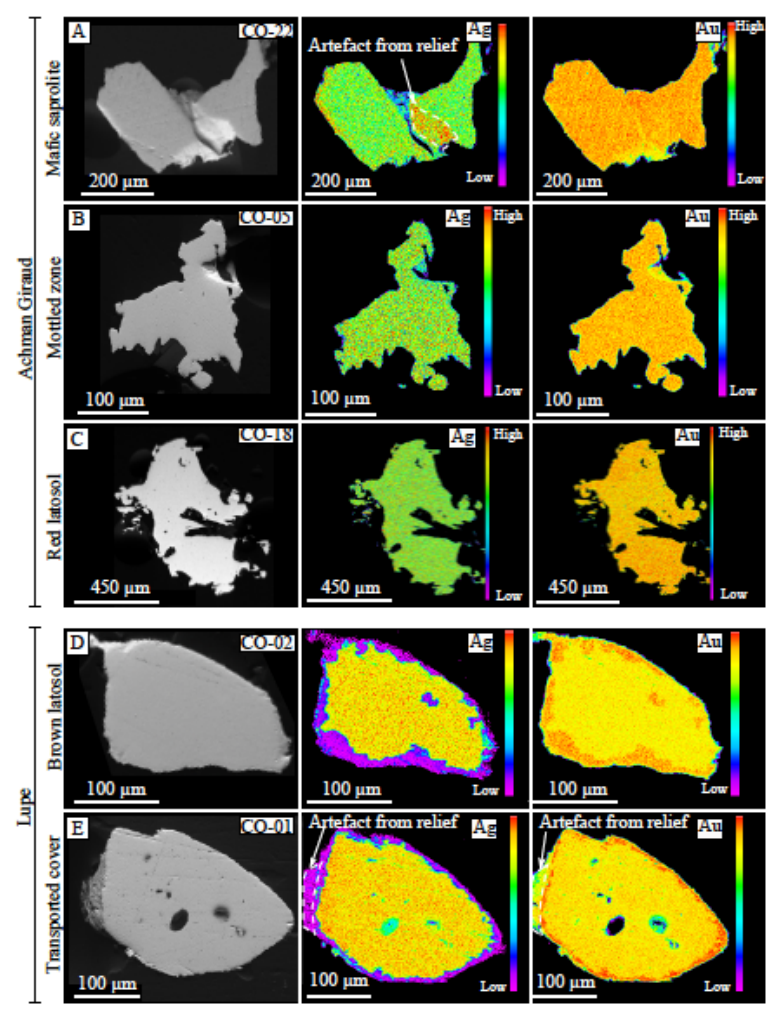

Fig. 14. Examples of EPMA mapping ( $\mathrm{Au}$ and $\mathrm{Ag}$ ) on panned grains. (A). Homogeneous grain from the saprolite at Achman Giraud. (B). Homogeneous grain from the mottled zone at Achman Giraud. (C). Homogeneous grain from the red latosol at Achman Giraud. (D). Heterogeneous grain from the brown latosol at Lupe with Ag-depleted rim and (E). Heterogeneous grain from the transported cover at Lupe with Ag-depleted rim.

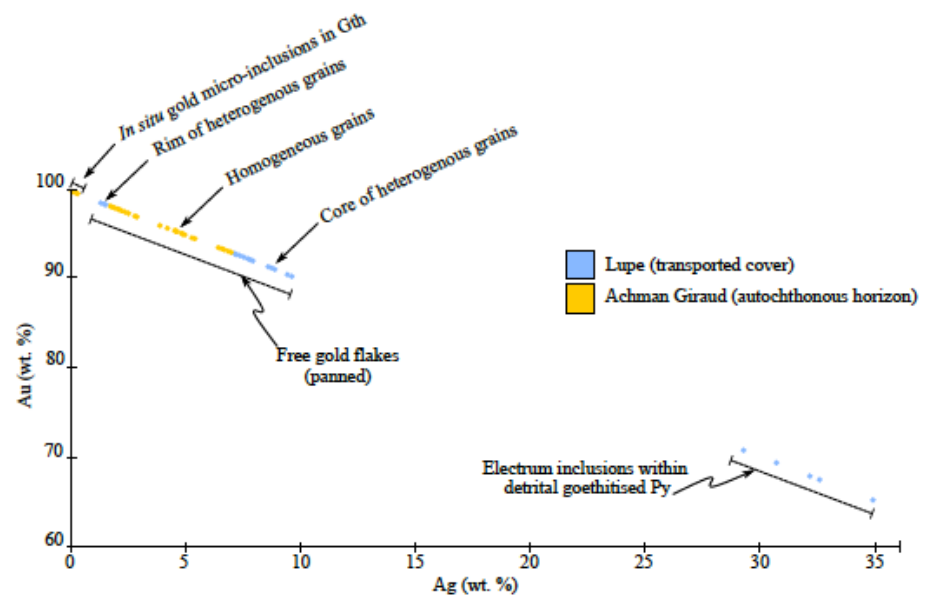

Fig. 15. Plot of Au vs Ag in wt.\% from EPMA analyses on the diverse gold types from the Achman Giraud and Lupe sites. 


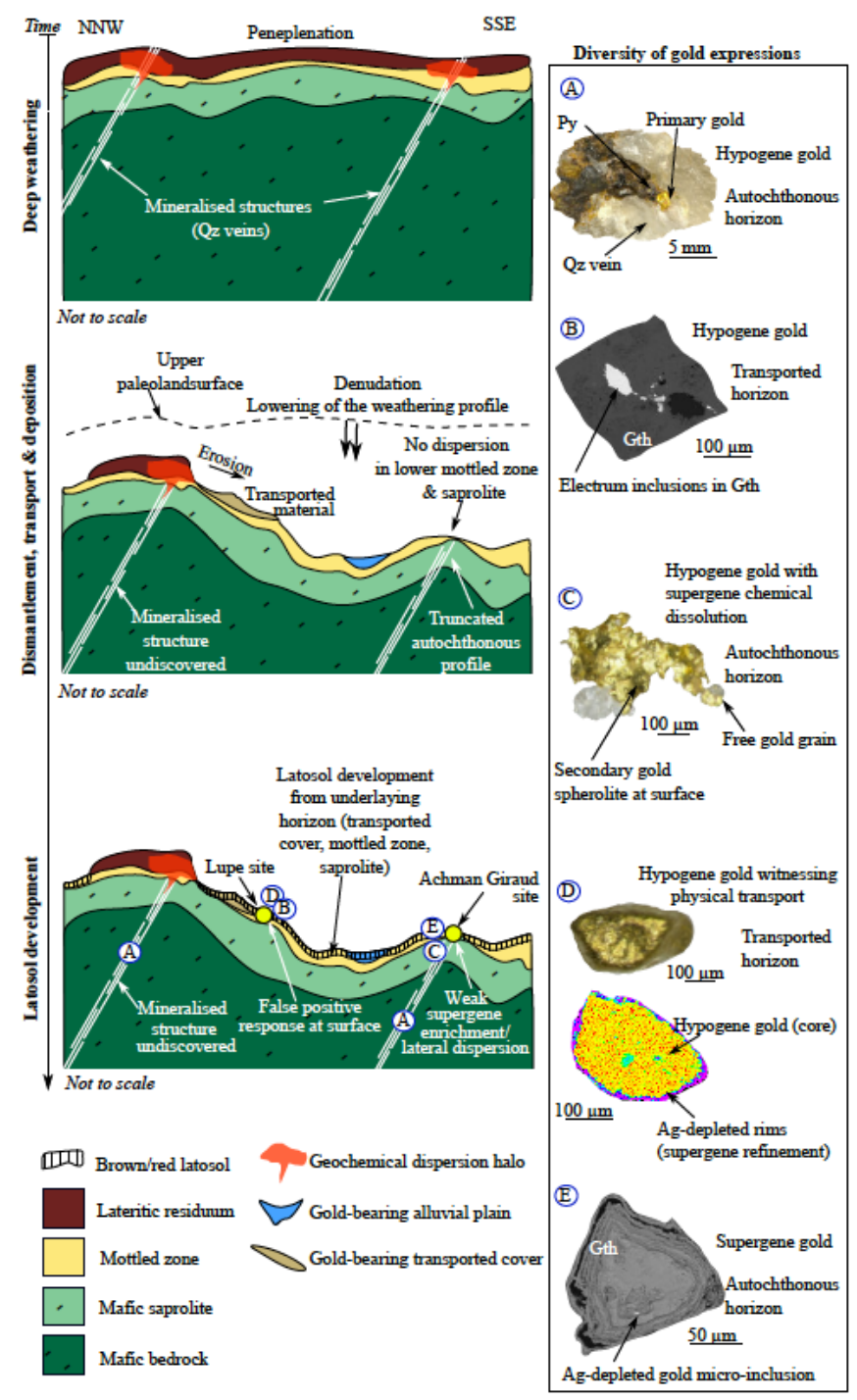

Fig. 16. Conceptual model for the formation of gold-bearing regolith in the Couriège area, illustrating the context in which gold expressions encountered in this study may be formed. The proposed model includes a deep weathering phase, followed by a dismantlement-transportdeposition phase and a late latosol development episode. 
1 Tables (Supplementary material)

2 Table 1. Major and trace element compositions of samples collected along the vertical P1 profile at Achman Giraud

\begin{tabular}{|c|c|c|c|c|c|c|c|c|c|c|c|c|c|c|c|c|c|c|c|c|c|}
\hline Sample ID & Horizon & $\mathrm{Zrppm}$ & As ppm & Ba ppm & Be ppm & Bi ppm & $\mathrm{Cd} \mathrm{ppm}$ & Co ppm & Cr ppm & Cs ppm & Cu ppm & Gappm & Ge ppm & Hf ppm & In ppm & Mo ppm & $\mathrm{Nb}$ ppm & Ni ppm & $\mathrm{Pb} \mathrm{ppm}$ & $\mathrm{Rbppm}$ & $\mathrm{Sb} p \mathrm{pm}$ \\
\hline $\mathrm{CO}-14$ & Red latosol & 179.24 & bdl & 11.37 & 0.55 & 0.22 & 0.04 & 4.56 & 109.23 & 0.06 & 40.49 & 29.14 & 1.81 & 4.73 & 0.07 & 0.6 & 7.43 & 64.45 & 8.86 & 0.47 & 0.07 \\
\hline CO-15 & Red latosol & 174.58 & bdl & 17.56 & 0.76 & 0.49 & 0.03 & 4.9 & 119.89 & 0.04 & 46.46 & 28.16 & 1.77 & 4.6 & 0.06 & bdl & 7.28 & 62.04 & 7.86 & 0.39 & bdl \\
\hline $\mathrm{CO}-16$ & Red latosol & 154.46 & bdl & 21.18 & 0.72 & 2.65 & 0.03 & 6.72 & 242.94 & 0.05 & 65.96 & 27.7 & 1.8 & 4.03 & 0.07 & 0.62 & 6.67 & 92.56 & 7.57 & 0.49 & bdl \\
\hline $\mathrm{CO}-17$ & Red latosol & 171.87 & 0.67 & 10.66 & 0.45 & 0.2 & 0.03 & 3.52 & 167.23 & 0.07 & 34.45 & 27.36 & 1.64 & 4.56 & 0.07 & 1.07 & 7.67 & 32.52 & 8.12 & 0.43 & 0.09 \\
\hline $\mathrm{CO}-18$ & Red latosol & 194.13 & 0.53 & 64.67 & 0.9 & 0.87 & 0.04 & 9.13 & 191.03 & 0.09 & 82.53 & 38.44 & 2.09 & 5.07 & 0.12 & bdl & 8.91 & 84.85 & 11.75 & 1.53 & 0.07 \\
\hline $\mathrm{CO}-19$ & Red latosol & 168.3 & bdl & 35.42 & 0.74 & 0.56 & 0.04 & 8.44 & 315.13 & 0.1 & 61.08 & 32.03 & 2.05 & 4.47 & 0.1 & bdl & 7.49 & 68.79 & 9.98 & 2.57 & bdl \\
\hline $\mathrm{CO}-20$ & Red latosol & 156.69 & 0.51 & 18.51 & 0.72 & 0.3 & 0.05 & 6.76 & 128.93 & 0.07 & 49.89 & 25.57 & 1.89 & 4.15 & 0.06 & bdl & 6.45 & 59.64 & 12.31 & 1.03 & 0.07 \\
\hline $\mathrm{CO}-21$ & Red latosol & 141.06 & 0.54 & 17.87 & 0.59 & 0.31 & 0.05 & 10.13 & 140.48 & 0.06 & 73.69 & 23.65 & 1.92 & 3.71 & 0.06 & bdl & 5.98 & 67.94 & 12.38 & 0.53 & 0.08 \\
\hline $\mathrm{CO}-22$ & Saprolite & 91.62 & 0.5 & 60.41 & 0.46 & 0.78 & 0.04 & 60.06 & 174.31 & 0.07 & 115.21 & 18.53 & 2.02 & 2.4 & 0.05 & 0.87 & 3.96 & 130.28 & 19.72 & 0.6 & 0.06 \\
\hline $\mathrm{CO}-23$ & Saprolite & 145.05 & 0.77 & 50.96 & 0.64 & 0.43 & 0.07 & 31.86 & 180.88 & 0.07 & 80.82 & 24.82 & 1.9 & 3.78 & 0.05 & 0.76 & 5.83 & 69.71 & 48.78 & 1.23 & 0.11 \\
\hline CO-24 & Saprolite & 164.08 & 2.47 & 48.96 & 0.61 & 0.76 & 0.21 & 20.58 & 139.54 & 0.09 & 143.66 & 28.5 & 1.68 & 4.22 & 0.05 & 0.54 & 6.65 & 52.17 & 46.08 & 1.67 & 0.35 \\
\hline $\mathrm{CO}-25$ & Saprolite & 192.47 & 4.93 & 198.14 & 0.62 & 1.65 & 0.36 & 54.09 & 176.55 & 0.48 & 196.07 & 33.69 & 2.33 & 5.03 & 0.06 & 1.59 & 7.42 & 89.31 & 109.55 & 18.14 & 0.7 \\
\hline $\mathrm{CO} 33$ & Bedrock & 118.61 & bdl & 893.64 & 0.92 & 0.17 & 0.06 & 26.95 & 120.68 & 0.66 & 136.02 & 18.35 & 1.39 & 3.09 & 0.05 & 0.68 & 4.53 & 44.36 & 7.21 & 44.93 & 0.07 \\
\hline Sample ID & Horizon & Sc ppm & Sn ppm & Sr ppm & Ta ppm & Th ppm & U ppm & V ppm & W ppm & Y ppm & $\mathrm{Zn} \mathrm{ppm}$ & Zr ppm & La ppm & Ce ppm & Pr ppm & $\mathrm{Nd} \mathrm{ppm}$ & Sm ppm & Eu ppm & Gd ppm & Tb ppm & Dy ppm \\
\hline $\mathrm{CO}-14$ & Red latosol & 24.35 & 1.33 & bdl & 0.67 & 5.33 & 1.89 & 203.65 & 0.88 & 2.15 & 49.62 & 179.24 & 1.17 & 12.09 & 0.4 & 1.63 & 0.51 & 0.23 & 0.45 & 0.09 & 0.61 \\
\hline $\mathrm{CO}-15$ & Red latosol & 27.32 & 1.52 & 0.85 & 0.67 & 5.21 & 2.05 & 219.97 & 5.84 & 2.89 & 71.91 & 174.58 & 1.62 & 11.23 & 0.47 & 1.83 & 0.59 & 0.29 & 0.58 & 0.13 & 0.89 \\
\hline $\mathrm{CO}-16$ & Red latosol & 23.95 & 1.49 & bdl & 0.59 & 4.62 & 1.98 & 192.48 & 4.01 & 2.91 & 85.67 & 154.46 & 1.09 & 6.36 & 0.35 & 1.37 & 0.5 & 0.25 & 0.54 & 0.13 & 0.93 \\
\hline $\mathrm{CO}-17$ & Red latosol & 32.28 & 1.4 & 1.63 & 0.7 & 5.18 & 1.65 & 207.87 & bdl & 2.76 & 32.85 & 171.87 & 2.6 & 19.84 & 0.68 & 2.63 & 0.62 & 0.22 & 0.55 & 0.09 & 0.64 \\
\hline $\mathrm{CO}-18$ & Red latosol & 30.54 & 2.36 & 1.16 & 0.75 & 5.94 & 2.51 & 275.62 & 2.8 & 3.88 & 81.34 & 194.13 & 2.04 & 11.15 & 0.5 & 1.95 & 0.7 & 0.34 & 0.79 & 0.18 & 1.28 \\
\hline $\mathrm{CO}-19$ & Red latosol & 30.52 & 1.87 & 0.74 & 0.65 & 5.12 & 2.63 & 259.05 & 1.99 & 3.63 & 45.5 & 168.3 & 2.07 & 13.13 & 0.45 & 1.76 & 0.61 & 0.3 & 0.67 & 0.15 & 1.05 \\
\hline $\mathrm{CO}-20$ & Red latosol & 24.84 & 1.35 & 3.4 & 0.58 & 4.57 & 2.7 & 189.65 & 0.88 & 3.22 & 42.51 & 156.69 & 6.06 & 13.9 & 0.89 & 2.93 & 0.72 & 0.3 & 0.68 & 0.13 & 0.9 \\
\hline $\mathrm{CO}-21$ & Red latosol & 23.73 & 1.4 & 4.24 & 0.54 & 4.36 & 2.41 & 171.67 & bdl & 2.93 & 32.78 & 141.06 & 5.37 & 17.23 & 0.89 & 3.03 & 0.68 & 0.26 & 0.6 & 0.12 & 0.8 \\
\hline CO-22 & Saprolite & 24.94 & 0.97 & 0.91 & 0.35 & 2.69 & 2.15 & 152.6 & 1.18 & 2.18 & 45.31 & 91.62 & 2.2 & 605.62 & 0.54 & 1.9 & 0.54 & 0.21 & 1.69 & 0.12 & 0.59 \\
\hline $\mathrm{CO}-23$ & Saprolite & 24.22 & 1.49 & 17.56 & 0.52 & 4.25 & 2.33 & 168.94 & 1.62 & 4.33 & 42.02 & 145.05 & 93.54 & 260.29 & 12.94 & 33.47 & 4.53 & 1.17 & 2.79 & 0.34 & 1.74 \\
\hline $\mathrm{CO}-24$ & Saprolite & 30.05 & 3.11 & 9.97 & 0.61 & 4.79 & 2.36 & 179.8 & 2.03 & 3.58 & 35.61 & 164.08 & 30.45 & 134.26 & 5.35 & 15.68 & 2.39 & 0.68 & 1.52 & 0.2 & 1.09 \\
\hline $\mathrm{CO}-25$ & Saprolite & 26.83 & 5.79 & 12.74 & 0.69 & 5.56 & 2.48 & 212.07 & 2.09 & 20.72 & 82.64 & 192.47 & 86.65 & 285.87 & 19.27 & 73.06 & 12.32 & 3.25 & 7.86 & 0.87 & 4.6 \\
\hline
\end{tabular}




\begin{tabular}{|c|c|c|c|c|c|c|c|c|c|c|c|c|c|c|c|c|c|c|}
\hline $\mathrm{CO} 33$ & Bedrock & 18.99 & 1.04 & 662.82 & 0.43 & 3.85 & 1.51 & 132.42 & bdl & 12.65 & 67.43 & 118.61 & 21.74 & 43.41 & 5.36 & 21.04 & 4.03 & 1.25 \\
\hline Sample ID & Horizon & Ho ppm & Er ppm & Tm ppm & $\mathrm{Yb}$ ppm & Lu ppm & $\mathrm{SiO}_{2}$ wt. $\%$ & $\mathrm{Al}_{2} \mathrm{O}_{3}$ wt. $\%$ & $\mathrm{Fe}_{2} \mathrm{O}_{3}$ wt. \% & MnO wt. \% & MgO wt. \% & $\mathrm{CaO}$ wt. $\%$ & $\mathrm{Na} 2 \mathrm{O}$ wt. $\%$ & $\mathrm{~K} 2 \mathrm{O}$ wt. $\%$ & $\mathrm{TiO}_{2}$ wt. $\%$ & $\mathrm{P}_{2} \mathrm{O}$ s wt. $\%$ & LOI wt. \% & Total \\
\hline $\mathrm{CO}-14$ & Red latosol & 0.13 & 0.4 & 0.07 & 0.66 & 0.11 & 57.49 & 20.55 & 11.6 & 0.02 & bdl & bdl & bdl & bdl & 1.01 & bdl & 9.35 & 100.02 \\
\hline $\mathrm{CO}-15$ & Red latosol & 0.19 & 0.56 & 0.1 & 0.86 & 0.14 & 57.56 & 19.54 & 12.46 & 0.02 & bdl & bdl & bdl & bdl & 1.01 & bdl & 9.67 & 100.26 \\
\hline $\mathrm{CO}-16$ & Red latosol & 0.19 & 0.58 & 0.11 & 0.92 & 0.15 & 62.82 & 17.22 & 11.15 & bdl & bdl & bdl & bdl & bdl & 0.91 & bdl & 8.23 & 100.33 \\
\hline $\mathrm{CO}-17$ & Red latosol & 0.14 & 0.42 & 0.08 & 0.66 & 0.11 & 56.53 & 20.49 & 12.22 & 0.04 & bdl & bdl & bdl & bdl & 1.07 & bdl & 10.04 & 100.39 \\
\hline $\mathrm{CO}-18$ & Red latosol & 0.26 & 0.76 & 0.14 & 1.17 & 0.18 & 53.49 & 22.61 & 12.68 & 0.03 & bdl & bdl & bdl & 0.06 & 1.11 & bdl & 10.33 & 100.31 \\
\hline CO-19 & Red latosol & 0.22 & 0.67 & 0.12 & 1.03 & 0.16 & 52.42 & 24.03 & 11.02 & 0.02 & 0.04 & bdl & bdl & 0.09 & 0.94 & bdl & 11.36 & 99.92 \\
\hline $\mathrm{CO}-20$ & Red latosol & 0.18 & 0.54 & 0.1 & 0.84 & 0.14 & 54.59 & 22.97 & 10.45 & 0.02 & 0.03 & bdl & bdl & 0.04 & 0.87 & bdl & 10.74 & 99.69 \\
\hline $\mathrm{CO}-21$ & Red latosol & 0.17 & 0.5 & 0.1 & 0.8 & 0.13 & 52.36 & 25.07 & 10.17 & 0.02 & bdl & bdl & bdl & bdl & 0.81 & bdl & 11.52 & 99.95 \\
\hline $\mathrm{CO}-22$ & Saprolite & 0.13 & 0.38 & 0.07 & 0.59 & 0.1 & 53.58 & 26.14 & 7.42 & 0.08 & 0.03 & bdl & bdl & bdl & 0.49 & bdl & 11.95 & 99.69 \\
\hline $\mathrm{CO}-23$ & Saprolite & 0.29 & 0.77 & 0.13 & 1.02 & 0.17 & 62.26 & 19.49 & 9.17 & 0.05 & 0.04 & bdl & bdl & 0.04 & 0.72 & bdl & 8.62 & 100.4 \\
\hline $\mathrm{CO}-24$ & Saprolite & 0.19 & 0.53 & 0.09 & 0.76 & 0.13 & 54.57 & 24.35 & 9.4 & 0.02 & 0.07 & bdl & bdl & 0.06 & 0.79 & bdl & 10.86 & 100.11 \\
\hline $\mathrm{CO}-25$ & Saprolite & 0.89 & 2.37 & 0.36 & 2.42 & 0.39 & 49.21 & 25.82 & 10.71 & 0.07 & 0.75 & bdl & bdl & 0.52 & 0.85 & bdl & 12.45 & 100.37 \\
\hline $\mathrm{CO} 33$ & Bedrock & 0.47 & 1.28 & 0.19 & 1.25 & 0.19 & 62.91 & 15.41 & 6.58 & 0.07 & 2.43 & 5.77 & 2.63 & 1.58 & 0.59 & 0.15 & 1.42 & 99.52 \\
\hline
\end{tabular}

3 
8 Table 2. Gold grade analyses for each sample from Achman Giraud and Lupe sites.

9

\begin{tabular}{|c|c|c|c|}
\hline Sample ID & Sample location & Horizon & $\mathrm{Au}(\mathrm{ppm})$ \\
\hline $\mathrm{CO}-02$ & Lupe & Red latosol & 0.23 \\
\hline $\mathrm{CO}-03$ & Lupe & Mottled zone & 0.05 \\
\hline CO-04 & Lupe & Mottled zone & 0.07 \\
\hline $\mathrm{CO}-05$ & Achman Giraud & Mottled zone & 0.61 \\
\hline $\mathrm{CO}-06$ & Achman Giraud & Mottled zone & 0.28 \\
\hline $\mathrm{CO}-07$ & Achman Giraud & Mottled zone & 0.3 \\
\hline $\mathrm{CO}-08$ & Achman Giraud & Mottled zone & 0.1 \\
\hline CO-09 & Achman Giraud & Mottled zone & 0.03 \\
\hline $\mathrm{CO}-10$ & Achman Giraud & Mottled zone & 0.48 \\
\hline CO-11 & Achman Giraud & Saprolite & 0.64 \\
\hline $\mathrm{CO}-14$ & Achman Giraud & Red latosol & 7.14 \\
\hline CO-15 & Achman Giraud & Red latosol & 0.22 \\
\hline CO-16 & Achman Giraud & Red latosol & 4.89 \\
\hline $\mathrm{CO}-17$ & Achman Giraud & Red latosol & 0.37 \\
\hline CO-18 & Achman Giraud & Red latosol & 1.01 \\
\hline CO-19 & Achman Giraud & Red latosol & 0.41 \\
\hline CO-20 & Achman Giraud & Red latosol & 0.16 \\
\hline $\mathrm{CO}-21$ & Achman Giraud & Red latosol & 0.3 \\
\hline $\mathrm{CO}-22$ & Achman Giraud & Saprolite & 5.39 \\
\hline $\mathrm{CO}-23$ & Achman Giraud & Saprolite & 0.31 \\
\hline $\mathrm{CO}-24$ & Achman Giraud & Saprolite & 0.24 \\
\hline $\mathrm{CO}-25$ & Achman Giraud & Saprolite & 0.28 \\
\hline $\mathrm{CO}-26$ & Achman Giraud & Red latosol & 0.05 \\
\hline $\mathrm{CO}-27$ & Achman Giraud & Red latosol & 0.08 \\
\hline $\mathrm{CO}-28$ & Achman Giraud & Red latosol & 0.07 \\
\hline CO-29 & Achman Giraud & Red latosol & 1.11 \\
\hline
\end{tabular}


23 Table 3. EPMA analyses of Ag and Au for all gold types sampled at Achman Giraud and Lupe.

\begin{tabular}{|c|c|c|c|c|c|}
\hline Sample ID & Sample location & Horizon & Gold type & $\mathrm{Ag}(\mathrm{ppm})$ & $\mathrm{Au}(\mathrm{ppm})$ \\
\hline P1-g18-1 & Achman Giraud & Red latosol & Free gold (panned) & 1.99 & 99.25 \\
\hline P1-g18-2 & Achman Giraud & Red latosol & Free gold & 2.2 & 98.68 \\
\hline P1-g18-3 & Achman Giraud & Red latosol & Free gold & 2.4 & 98.56 \\
\hline P1-g18-4 & Achman Giraud & Red latosol & Free gold & 1.76 & 99.35 \\
\hline P1-g5-1 & Achman Giraud & Mottled zone & Free gold & 2.31 & 97.82 \\
\hline P1-g5-2 & Achman Giraud & Mottled zone & Free gold & 2.33 & 98.25 \\
\hline P1-g5-3 & Achman Giraud & Mottled zone & Free gold & 2.45 & 98.39 \\
\hline P2-g5-1 & Achman Giraud & Mottled zone & Free gold & 2.3 & 98.92 \\
\hline P2-g5-2 & Achman Giraud & Mottled zone & Free gold & 2.3 & 99.38 \\
\hline P2-g5-3 & Achman Giraud & Mottled zone & Free gold & 2.33 & 100.32 \\
\hline P2-g5-4 & Achman Giraud & Mottled zone & Free gold & 2.4 & 97.62 \\
\hline P2-g5-5 & Achman Giraud & Mottled zone & Free gold & 2.26 & 98.85 \\
\hline P2-g5-6 & Achman Giraud & Mottled zone & Free gold & 2.15 & 97.89 \\
\hline P2-g5-7 & Achman Giraud & Mottled zone & Free gold & 2.33 & 98.33 \\
\hline P2-g5-8 & Achman Giraud & Mottled zone & Free gold & 2.34 & 99.5 \\
\hline P2-g5-9 & Achman Giraud & Mottled zone & Free gold & 2.67 & 98.27 \\
\hline P2-g5-10 & Achman Giraud & Mottled zone & Free gold & 2.83 & 97.44 \\
\hline P2-g2-1 & Lupe & Brown latosol & Free gold & 7.69 & 93.29 \\
\hline P2-g2-2 & Lupe & Brown latosol & Free gold & 7.72 & 93.25 \\
\hline P2-g2-3 & Lupe & Brown latosol & Free gold & 7.98 & 93.74 \\
\hline P2-g2-4 & Lupe & Brown latosol & Free gold & 7.5 & 93.22 \\
\hline P2-g2-5 & Lupe & Brown latosol & Free gold & 3.85 & 95.27 \\
\hline P2-g2-6 & Lupe & Brown latosol & Free gold & 6.42 & 91.56 \\
\hline P2-g18-1 & Achman Giraud & Red latosol & Free gold & 1.98 & 99.12 \\
\hline P2-g18-2 & Achman Giraud & Red latosol & Free gold & 1.74 & 99.53 \\
\hline P2-g18-3 & Achman Giraud & Red latosol & Free gold & 2.26 & 99.46 \\
\hline P3-g27-1 & Achman Giraud & Red latosol & Free gold & 1.47 & 99.72 \\
\hline P3-g27-2 & Achman Giraud & Red latosol & Free gold & 1.56 & 99.24 \\
\hline P3-g27-3 & Achman Giraud & Red latosol & Free gold & 1.84 & 97.32 \\
\hline P3-g27-4 & Achman Giraud & Red latosol & Free gold & 1.78 & 100.26 \\
\hline P3-g27-5 & Achman Giraud & Red latosol & Free gold & 1.98 & 98.55 \\
\hline P3-g27-6 & Achman Giraud & Red latosol & Free gold & 1.46 & 98.38 \\
\hline P3-g18-1 & Achman Giraud & Red latosol & Free gold & 1.85 & 97.87 \\
\hline P3-g18-2 & Achman Giraud & Red latosol & Free gold & 2.12 & 99.42 \\
\hline P3-g18-3 & Achman Giraud & Red latosol & Free gold & 1.74 & 99.65 \\
\hline P3-g18-4 & Achman Giraud & Red latosol & Free gold & 2.2 & 98.5 \\
\hline P3-g18-5 & Achman Giraud & Red latosol & Free gold & 2.19 & 99.35 \\
\hline P3-g16-1 & Achman Giraud & Red latosol & Free gold & 2.28 & 98.47 \\
\hline P3-g16-2 & Achman Giraud & Red latosol & Free gold & 2.26 & 98.44 \\
\hline P3-g16-3 & Achman Giraud & Red latosol & Free gold & 2.22 & 97.2 \\
\hline P3-g16-4 & Achman Giraud & Red latosol & Free gold & 2.09 & 97.2 \\
\hline P3-g16-5 & Achman Giraud & Red latosol & Free gold & 4.57 & 96.52 \\
\hline P3-g16-6 & Achman Giraud & Red latosol & Free gold & 4.29 & 97.71 \\
\hline P3-g16-7 & Achman Giraud & Red latosol & Free gold & 4.88 & 94.72 \\
\hline P3-g16-8 & Achman Giraud & Red latosol & Free gold & 4.68 & 96.66 \\
\hline
\end{tabular}




\begin{tabular}{|c|c|c|c|c|c|}
\hline P3-g05-1 & Achman Giraud & Mottled zone & Free gold & 2.39 & 99.12 \\
\hline P3-g05-2 & Achman Giraud & Mottled zone & Free gold & 2.92 & 97.73 \\
\hline P3-g05-3 & Achman Giraud & Mottled zone & Free gold & 2.62 & 98.22 \\
\hline P3-g05-4 & Achman Giraud & Mottled zone & Free gold & 2.69 & 98.92 \\
\hline P3-g22-1 & Achman Giraud & Saprolite & Free gold & 2.49 & 99.33 \\
\hline P3-g22-2 & Achman Giraud & Saprolite & Free gold & 2.69 & 96.73 \\
\hline P3-g22-3 & Achman Giraud & Saprolite & Free gold & 2.91 & 98.81 \\
\hline P3-g19-1 & Achman Giraud & Red latosol & Free gold & 2.05 & 99.28 \\
\hline P3-g19-2 & Achman Giraud & Red latosol & Free gold & 2.06 & 98.13 \\
\hline P3-g19-3 & Achman Giraud & Red latosol & Free gold & 2.06 & 99.16 \\
\hline P3-g19-4 & Achman Giraud & Red latosol & Free gold & 1.71 & 98.14 \\
\hline P3-g19-5 & Achman Giraud & Red latosol & Free gold & 4.27 & 97.22 \\
\hline P3-g19-6 & Achman Giraud & Red latosol & Free gold & 4.73 & 98.01 \\
\hline P3-g19-7 & Achman Giraud & Red latosol & Free gold & 4.6 & 96.65 \\
\hline P3-g19-8 & Achman Giraud & Red latosol & Free gold & 4.84 & 96.48 \\
\hline P4-g02-1 & Lupe & Brown latosol & Free gold & 7.79 & 94.21 \\
\hline P4-g02-2 & Lupe & Brown latosol & Free gold & 7.28 & 92.96 \\
\hline P4-g02-3 & Lupe & Brown latosol & Free gold & 7.78 & 93.92 \\
\hline P4-g02-4 & Lupe & Brown latosol & Free gold & 7.85 & 93.01 \\
\hline P4-g02-5 & Lupe & Brown latosol & Free gold & 7.38 & 92.67 \\
\hline P4-g01-2 & Lupe & Transported cover & Free gold & 2.64 & 98.14 \\
\hline P4-g01-3 & Lupe & Transported cover & Free gold & 2.44 & 98.87 \\
\hline P4-g01-4 & Lupe & Transported cover & Free gold & 0.28 & 101.54 \\
\hline P4-g01-5 & Lupe & Transported cover & Free gold & 8.98 & 93.09 \\
\hline P4-g01-6 & Lupe & Transported cover & Free gold & 8.77 & 93.17 \\
\hline P4-g01-7 & Lupe & Transported cover & Free gold & 9.82 & 93.08 \\
\hline P4-g01-8 & Lupe & Transported cover & Free gold & 8.75 & 92.33 \\
\hline P4-g19-1 & Achman Giraud & Red latosol & Free gold & 2.11 & 98.87 \\
\hline P4-g19-2 & Achman Giraud & Red latosol & Free gold & 2 & 97.96 \\
\hline P4-g19-3 & Achman Giraud & Red latosol & Free gold & 1.34 & 94.93 \\
\hline P4-g19-4 & Achman Giraud & Red latosol & Free gold & 4.8 & 94.28 \\
\hline P4-g19-5 & Achman Giraud & Red latosol & Free gold & 5.45 & 96.92 \\
\hline P4-g19-6 & Achman Giraud & Red latosol & Free gold & 5.43 & 95.58 \\
\hline P4-g21-1 & Achman Giraud & Red latosol & Free gold & 6.82 & 93.92 \\
\hline P4-g21-2 & Achman Giraud & Red latosol & Free gold & 6.68 & 94.24 \\
\hline P4-g21-3 & Achman Giraud & Red latosol & Free gold & 7.17 & 94.33 \\
\hline P4-g21-4 & Achman Giraud & Red latosol & Free gold & 6.9 & 94.04 \\
\hline P4-g21-5 & Achman Giraud & Red latosol & Free gold & 6.3 & 91.87 \\
\hline P4-g21-6 & Achman Giraud & Red latosol & Free gold & 2.46 & 99.31 \\
\hline P4-g21-7 & Achman Giraud & Red latosol & Free gold & 2.07 & 98.25 \\
\hline P4-g21-8 & Achman Giraud & Red latosol & Free gold & 2.31 & 98.26 \\
\hline P4-g21-9 & Achman Giraud & Red latosol & Free gold & 1.41 & 98.58 \\
\hline P4-g21-10 & Achman Giraud & Red latosol & Free gold & 1.72 & 98.86 \\
\hline P4-g21-11 & Achman Giraud & Red latosol & Free gold & 1.61 & 99.06 \\
\hline P4-g21-12 & Achman Giraud & Red latosol & Free gold & 1.84 & 98.22 \\
\hline P4-g21-13 & Achman Giraud & Red latosol & Free gold & 1.92 & 99.77 \\
\hline $16-\mathrm{IN}-1$ & Achman Giraud & Red latosol & Micro-inclusion & 0.1 & 99.5 \\
\hline $16-\mathrm{IN}-2$ & Achman Giraud & Red latosol & Micro-inclusion & 0.1 & 99.5 \\
\hline
\end{tabular}




\begin{tabular}{ccccccc} 
16-IN-3 & Achman Giraud & Red latosol & Micro-inclusion & 0.1 & 99.5 \\
16-IN-4 & Achman Giraud & Red latosol & Micro-inclusion & 0.1 & 99.5 \\
16-IN-5 & Achman Giraud & Red latosol & Micro-inclusion & 0.1 & 99.5 \\
$32 \mathrm{~A}$ & Lupe & Transported cover & Micro-inclusion & 32.6 & 67.4 \\
32A & Lupe & Transported cover & Micro-inclusion & 32.2 & 67.8 \\
32A & Lupe & Transported cover & Micro-inclusion & 30.8 & 69.2 \\
32A & Lupe & Transported cover & Micro-inclusion & 35 & 65 \\
32A & Lupe & Transported cover & Micro-inclusion & 29.3 & 70.7 \\
\hline
\end{tabular}

25

26

29

30

32

33

35

36

38

39

40

41

43

44

45

46

48

49

51 
52 Table 4. Trace element compositions of panned free gold grains (LA-ICPMS) and

53 corresponding EPMA analyses of Ag at the same spot. (**=EPMA)

\begin{tabular}{|c|c|c|c|c|c|c|c|c|c|c|c|c|c|c|}
\hline Sample ID & Sample location & Horizon & $\mathrm{Cu}$ & $\mathrm{Pd}$ & $\mathrm{Cd}$ & $\mathrm{Cr}$ & $\mathrm{Fe}$ & $\mathrm{Rh}$ & $\mathrm{Sb}$ & $\mathrm{Pt}$ & $\mathrm{Bi}$ & $\mathrm{Cd}$ & ${ }^{109} \mathrm{Ag}(*) .(\mathrm{ppm})$ & $\operatorname{Ag}(* *) .($ wt. \%) \\
\hline $\begin{array}{c}\text { Detection limit } \\
\text { maximum } \\
\text { value }\end{array}$ & & & 0.519 & 0.098 & 0.026 & 0.266 & 5.645 & 0.008 & 0.029 & 0.009 & 0.004 & 0.026 & 0.421 & \\
\hline P1-01 & Achman Giraud & Red latosol & 688 & 0.42 & 0.61 & bdl & bdl & bdl & bdl & 0.023 & bdl & 0.612 & 40590 & 4.04 \\
\hline P1-3 & Achman Giraud & Red latosol & 454.8 & 0.23 & 0.31 & bdl & bdl & bdl & bdl & bdl & bdl & 0.309 & 30070 & 3.76 \\
\hline P1-4 & Achman Giraud & Red latosol & 431.4 & 0.28 & 0.22 & bdl & bdl & bdl & bdl & 0.014 & bdl & 0.218 & 20260 & 2.28 \\
\hline P1-5 & Achman Giraud & Red latosol & 422 & 0.56 & 0.27 & bdl & bdl & bdl & bdl & bdl & bdl & bdl & 19790 & 2.67 \\
\hline P1-6 & Achman Giraud & Red latosol & 1021 & 0.33 & 0.9 & bdl & bdl & 0.008 & bdl & 0.014 & bdl & 0.903 & 19770 & 2.2 \\
\hline P1-7 & Achman Giraud & Red latosol & 1017 & 0.36 & 1.1 & bdl & bdl & 0.010 & bdl & 0.010 & bdl & 1.097 & 19990 & 2.2 \\
\hline P1-8 & Achman Giraud & Red latosol & 1023 & 0.37 & 1.07 & bdl & bdl & bdl & 0.090 & 0.013 & bdl & 1.066 & 19870 & 2.4 \\
\hline P1-9 & Achman Giraud & Mottled zone & 777 & 0.91 & 0.48 & bdl & bdl & bdl & bdl & bdl & bdl & bdl & 20010 & 2.2 \\
\hline P1-10 & Achman Giraud & Saprolite & 739 & 0.31 & 0.03 & bdl & bdl & 0.008 & bdl & 0.017 & bdl & 0.027 & 30020 & 4.22 \\
\hline P1-11 & Achman Giraud & Saprolite & 766 & 0.28 & 0.02 & bdl & bdl & bdl & bdl & 0.013 & bdl & bdl & 29730 & 4.08 \\
\hline P1-12 & Achman Giraud & Saprolite & 759 & 0.33 & 0.02 & bdl & bdl & 0.011 & bdl & bdl & bdl & bdl & 29800 & 3.98 \\
\hline P1-13 & Achman Giraud & Saprolite & 757 & 0.56 & 0.02 & bdl & bdl & bdl & bdl & 0.010 & bdl & bdl & 30200 & 3.88 \\
\hline P1-14 & Achman Giraud & Saprolite & 770 & 0.29 & 0.03 & bdl & bdl & bdl & bdl & 0.015 & bdl & 0.029 & 30140 & 3.98 \\
\hline P1-15 & Achman Giraud & Mottled zone & 686 & 0.79 & 0.29 & bdl & bdl & bdl & bdl & bdl & bdl & bdl & 20290 & 2.33 \\
\hline P2-1 & Achman Giraud & Mottled zone & 616 & 0.32 & 0.32 & bdl & bdl & bdl & 0.111 & 0.017 & 0.018 & 0.375 & 19840 & 2.33 \\
\hline P4-4 & Achman Giraud & Red latosol & 262 & 0.21 & 0.14 & bdl & bdl & bdl & bdl & bdl & bdl & bdl & 10100 & 1.34 \\
\hline P3-3 & Achman Giraud & Red latosol & 504 & 0.34 & 0.42 & bdl & bdl & bdl & bdl & 0.018 & bdl & 0.417 & 20450 & 2.37 \\
\hline P3-4 & Achman Giraud & Red latosol & 512 & 0.3 & 0.29 & bdl & bdl & bdl & bdl & bdl & bdl & bdl & 30160 & 3.81 \\
\hline P3-7 & Achman Giraud & Red latosol & 1152 & 0.45 & 1.81 & bdl & bdl & bdl & bdl & bdl & bdl & bdl & 19920 & 2.19 \\
\hline P3-8 & Achman Giraud & Red latosol & 442.3 & 0.24 & 0.84 & bdl & bdl & bdl & bdl & bdl & bdl & bdl & 20180 & 2.22 \\
\hline P3-9 & Achman Giraud & Red latosol & 376.8 & 0.22 & 0.71 & bdl & bdl & bdl & bdl & bdl & bdl & bdl & 19970 & 2.28 \\
\hline P3-10 & Achman Giraud & Red latosol & 432 & 0.54 & 0.14 & bdl & bdl & bdl & bdl & bdl & bdl & bdl & 39100 & 4.88 \\
\hline P3-11 & Achman Giraud & Mottled zone & 466 & 0.43 & 0.5 & 0.320 & bdl & bdl & bdl & 0.016 & bdl & 0.498 & 19520 & 2.92 \\
\hline P3-12 & Achman Giraud & Mottled zone & 461 & 0.45 & 0.57 & bdl & 7.100 & bdl & bdl & 0.016 & 0.008 & 0.571 & 20260 & 2.62 \\
\hline P3-14 & Achman Giraud & Saprolite & 299.6 & 0.21 & 0.1 & bdl & bdl & bdl & bdl & 0.012 & bdl & 0.095 & 19880 & 2.91 \\
\hline P3-15 & Achman Giraud & Saprolite & 300.4 & 0.2 & 0.1 & bdl & bdl & bdl & bdl & 0.010 & bdl & 0.096 & 20160 & 2.91 \\
\hline P3-16 & Achman Giraud & Saprolite & 615 & 0.5 & 3.14 & bdl & bdl & bdl & bdl & bdl & bdl & bdl & 19790 & 2.91 \\
\hline
\end{tabular}

54

$55 *$ corresponds to ${ }^{109} \mathrm{Ag}$ because ${ }^{107} \mathrm{Ag}$ is used as internal standard 